\title{
Dating the Tejo river lower terraces in the Ródão area (Portugal) to assess the role of tectonics and uplift
}

\author{
Pedro P. Cunha ${ }^{\mathrm{a}, *}$, António A. Martins ${ }^{\mathrm{b}}$, Sebastien Huot $^{\mathrm{c}}$, Andrew Murray $^{\mathrm{c}}$, Luís Raposo ${ }^{\mathrm{d}}$ \\ a IMAR-Instituto do Mar, Department of Earth Sciences, University of Coimbra, Largo Marquês de Pombal, 3000-272 Coimbra, Portugal \\ b Centro de Geofísica, Departamento de Geociências da Universidade de Évora, 7002-554 Évora, Portugal \\ c Nordic Laboratory for Luminescence Dating, Department of Earth Sciences, Aarhus University, Risø DTU, DK-4000 Roskilde, Denmark \\ d Museu Nacional de Arqueologia, Praça do Império, 1400 Lisbon, Portugal
}

\section{A R T I C L E I N F O}

\section{Article history:}

Received 25 January 2006

Received in revised form 1 April 2007

Accepted 3 May 2007

Available online 7 April 2008

\section{Keywords:}

Luminescence dating

Fluvial terraces

Tectonics

Incision rates

Uplift

Portugal

\begin{abstract}
A B S T R A C T
The Tejo river is one of the major drainages in Iberian Peninsula; it is a long-lived system (ca. $3.4 \mathrm{Ma}$ ) and provides an archive of long-term landscape development and environmental change controlled by tectonics, climate and eustasy. The most upstream Portuguese reach of the Tejo river, $\sim 200 \mathrm{~km}$ from the Atlantic coast, shows evidence for five fluvial terraces (T1 to T5) with elevations reaching more than $120 \mathrm{~m}$ above the modern river bed. A chronological framework for these terraces is established here by integrating geomorphological, stratigraphical and archaeological information with ages from luminescence dating. Optically stimulated luminescence dating of K-feldspar, (involving the correction for anomalous fading of the luminescence signal), indicates that the younger terraces have a probable age range of: T5 - 31 to $40 \mathrm{ka}$; and T4 -100 to $\sim 280 \mathrm{ka}$. We deduce that the related major fluvial changes are likely to have been as follows: $\sim 10 \mathrm{~m}$ of aggradation from 280 to $100 \mathrm{ka}(0.06 \mathrm{~m} / \mathrm{ka}) ; 14 \mathrm{~m}$ of incision from 100 to $40 \mathrm{ka}(0.23 \mathrm{~m} / \mathrm{ka}) ; 8 \mathrm{~m}$ of aggradation from 40 to $31 \mathrm{ka}(0.89 \mathrm{~m} / \mathrm{ka}) ; 16 \mathrm{~m}$ of incision during the last $31 \mathrm{ka}(0.52 \mathrm{~m} / \mathrm{ka})$. These values indicate that the duration and rate of both aggradation and river downcutting episodes were variable. There is widespread evidence for neotectonic activity in this intraplate region. Neither eustatic nor climatic changes during the Quaternary provide clear trends that might explain the observed pattern of valley incision, thus we conclude that this tectonic activity is the most likely driving mechanism. In the study area, the probable age of the Tejo river sediments deposited before the beginning of valley incision allows the calculation of a time-averaged incision rate of $\sim 0.07$ to $0.10 \mathrm{~m} / \mathrm{ka}$ over the last $\sim 2.6 \mathrm{Ma}$. This long-term incision was probably determined by an increase in the relative uplift rate, resulting from the intensification of intraplate compressive stress. During the late Cenozoic fluvial incision stage, the Ródão depression underwent less uplift than the adjacent areas along the river, in which the Tejo has incised a narrow valley into basement rock, with almost no terrace development. Terrace formation was also promoted by soft bedrock (Tertiary arkoses) and by impoundment of alluvium behind resistant barriers crossed by the river. Geomorphological evidence for terrace tectonic offset was also supported by luminescence dating.
\end{abstract}

(c) 2008 Elsevier B.V. All rights reserved.

\section{Introduction}

The Tejo, called Tajo in Spain, is the longest $(1007 \mathrm{~km})$ and one of the largest rivers of the Iberian Peninsula (catchment size of $78,463 \mathrm{~km}^{2}$ ), draining to the Atlantic Ocean (Fig. 1). Is a perennial fluvial system with a present average flow of $\sim 9 \mathrm{~km}^{3} \mathrm{yr}^{-1}(1952-1982)$ in the study area ( $\sim 200 \mathrm{~km}$ upstream of the Atlantic coast). Before dam construction, erosion affected most of the catchment and deposition was localized to the lower reaches (Portuguese reaches IV and V) and on the adjacent Atlantic margin.

\footnotetext{
* Corresponding author. Tel.: +351 239860 541; fax: +351 239860501.

E-mail addresses: pcunha@dct.uc.pt (P.P. Cunha), aam@uevora.pt (A.A. Martins), melpomene100@hotmail.com (S. Huot), andrew.murray@risoe.dk (A. Murray), 3raposos@mail.telepac.pt (L. Raposo).
}

The Tejo river has a varying number of fluvial terraces along its course, up to five in the Portuguese transect. In Spain, up to 12 terrace levels can be observed between Talavera de la Reina and Malpica (in the "Campo Arañuelo area, in the western part of the Madrid Tertiary Basin). In the Spanish sector, the terraces are stepped between $8 \mathrm{~m}$ and $195 \mathrm{~m}$ above the present-day alluvial plain (Pérez-González, 1994; Silva et al., 1997; Silva, 2003). There the river incision began on a surface (the "piedmont" of Valdelaosa, altitude $623 \mathrm{~m}$ ) much higher than that in the Portuguese Ródão area, where the incision started at an altitude of $\sim 300-350 \mathrm{~m}$ (top of the Falagueira Formation; these altitudes refer to present elevation above sea level). Some recent geomorphological studies of the Tejo terraces have been made in the Spanish sector (e.g. Pérez-González, 1994; Gutiérrez-Elorza et al., 2002) and in the Portuguese sector (Martins, 1999; Cunha et al., 2005). However, only few, relatively young terrace ages have been published; 
for the Portuguese sector twelve ages are known (four U-series and eight thermoluminescence ages; Raposo, 1995a; Raposo and Cardoso, 1998), all in the range 27 to $>127 \mathrm{ka}$.

Using the Tejo river as an example, we set out here to establish an absolute chronology for part of this large, long-lived fluvial system, where incision is considered to be driven primarily by tectonics (Cunha et al., 2005). The main aim of the present study is to use luminescence ages for the fluvial terraces to assess the main control on drainage development and to attempt to quantify changes in the incision rate during the Quaternary.

The study region lies in an intraplate moderate compressional continental setting resulting from the convergence between Africa and Iberia along the Azores-Gibraltar Fracture Zone and Atlantic ridge-push forces (e.g. Srivastava et al., 1990; Ribeiro et al., 1996). Ongoing intraplate deformation of Iberia is typically manifested by earthquake activity concentrated on the Pyrenees, Betic Orogen and Atlantic domain. Iberia is characterized by a consistent horizontal compressional stress field that is dominated by northwest-directed stress trajectories fanning out in Portugal into a more westerly direction and in northeastern Spain into a northerly direction (Andeweg et al., 1999). The magnitude of Plio-Pleistocene vertical motions suggests that process controlling topography development are still ongoing and exert a first-order control on the present topographic configuration of Iberia, characterized by a succession of highs and lows that trend normal to the present-day intraplate compressional stress trajectories (Cloetingh et al., 2005).
Studies of uplift-driven valley incision and river terrace formation over Quaternary time-scales have proposed extrinsic controls such as eustasy, climate or tectonics as driving mechanisms. However, neither eustatic nor climatic changes during the Quaternary (Shackleton and Opdyke, 1973) provide clear trends that might explain the patterns of valley incision recognised across Europe (Maddy, 1997). Tectonic controls on terrace formation have been widely reported in Europe, for example, in the Middle Rhine area (Brunnacker and Boenigk, 1983), Maas valley (Van den Berg, 1996) and England (Maddy, 1997; Bonnet et al., 2000). The elevation and estimated ages of the river gravel deposits of the Upper Thames Valley have been used by Maddy (1997) and Maddy et al. (2000) to calculate uplift rates by using a simple linear model. However, to determine the driving mechanisms for bedrock river incision more quantitative age constraints are required. New geochronological techniques, such as optically stimulated luminescence (OSL), and cosmogenic nuclide dating, are being used to obtain chronological frameworks in systems that were previously only poorly known.

Geomorphological and stratigraphical approaches, based on spatial relationships, allow the establishment of a relative chronological sequence of the geomorphological or sedimentary records and of the geological events they represent. However, it is often difficult to correlate terraces on adjacent reaches of the same river; similar depositional facies can exist at different terrace levels and significant vertical displacements of the same surface can be produced by active tectonics (Burbank and Anderson, 2001). By dating fluvial terraces

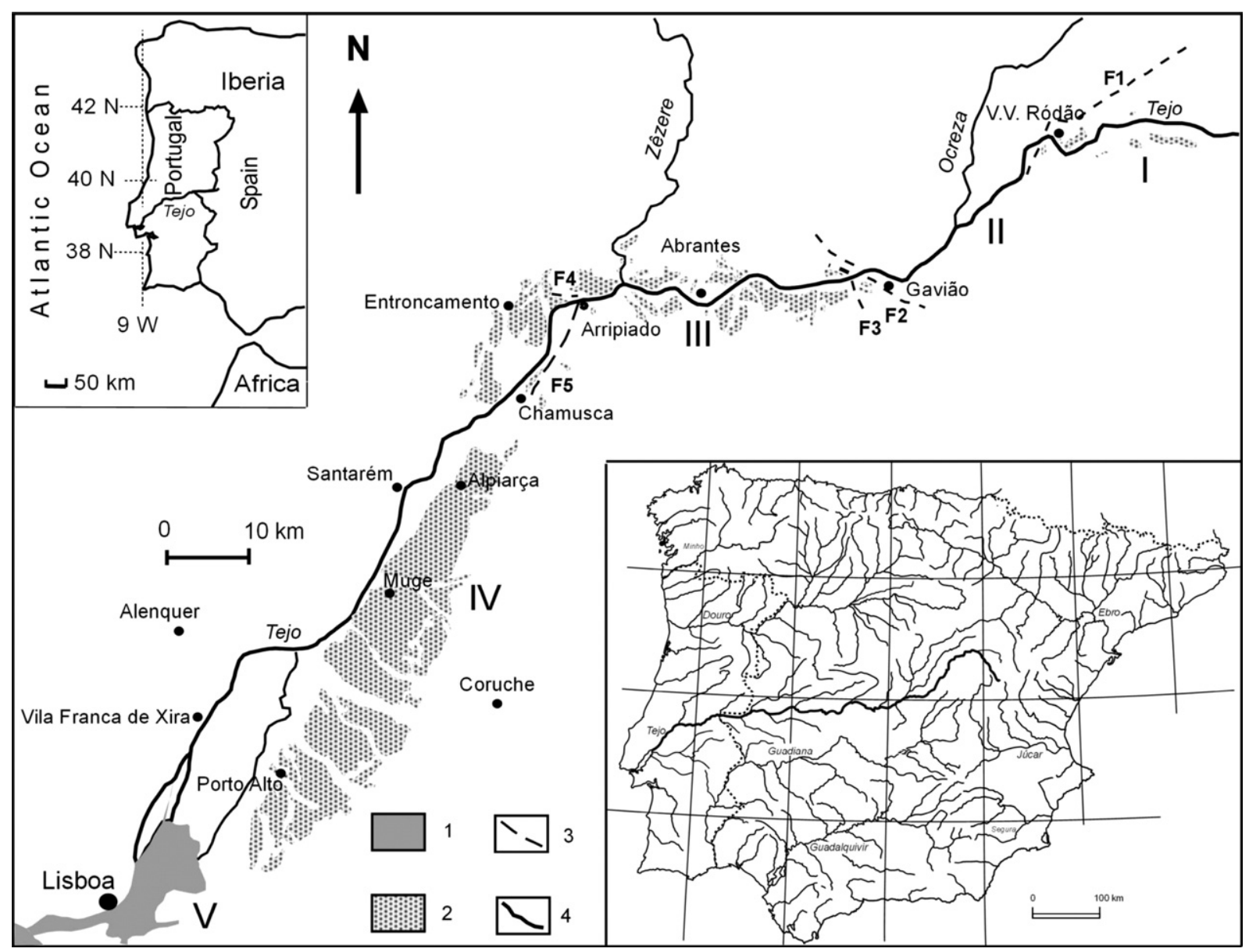

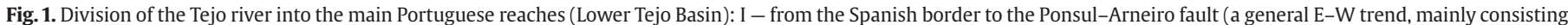

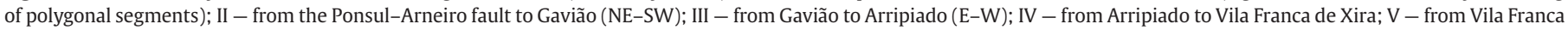

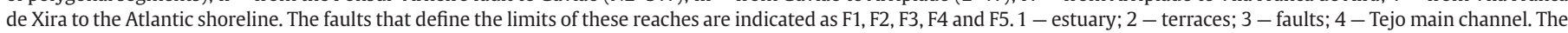
main Iberian drainage basins are also represented. 
such geomorphic markers can better be used to track deformation associated with active faults.

Integration of different types of dating, such as (1) relative, provided by geomorphological, stratigraphical and archaeological approaches, and (2) quantitative, resulting from the measurement of physical processes (absolute dating techniques), improves the temporal control of the main evolutionary stages of the landscape. This also helps us to understand controls on the long-term dynamics of a fluvial system, by assessing the interplay of tectonics, climate and eustasy.

A fluvial deposit may contain fossils (useful for biostratigraphy or paleoenvironmental reconstruction) and datable material which can be used to establish an independent geochronology; datable material can include: organics for radiocarbon age estimation; bone, travertine and other calcareous precipitates for U-series methods; and quartz or feldspar minerals extracted from the sediments for luminescence methods (e.g. Pederson et al., 2006). However, it is common that for a particular suite of terraces only some quantitative dating methods can be used. Luminescence dating offers a reliable and widely-applicable approach to the dating of fluvial sequences (Huntley and Lian, 1999; Wallinga, 2002). OSL dating of quartz has given well constrained chronologies for sediments with ages of a few decades to $>100 \mathrm{ka}$ (Murray and Olley, 2002). K-feldspar may also be used in OSL, but its accuracy is limited by a phenomenon known as anomalous fading (Aitken, 1998: Appendix D). Recently, Pedoja et al. (2006) successfully applied OSL from feldspar in conjunction with U/Th of corals to establish a chronology for marine terraces, with sediments as young as the marine isotopic stage (MIS) $5 \mathrm{e}(\sim 130 \mathrm{ka})$ to as old as MIS 9 ( $330 \mathrm{ka})$. Unfortunately, the unusually high dose rates of our studied sediments (4.1 to $7.0 \mathrm{~Gy} / \mathrm{ka}$ ) prevented the routine application of quartz OSL and so we have investigated the use of feldspar as an alternative for dating these terraces. The main aim of this study is to use K-feldspar infrared stimulated luminescence (IRSL) and TL dating to establish the terrace chronology.

\section{Geological and geomorphological setting}

\subsection{Geology}

In the study area, the basement consists of intensely folded PreCambrian to Lower Cambrian slates and metagreywackes, Ordovician quartzites and slates that occur in synclines, and alkaline plutons. The Tertiary sediments are divided into the Beira Baixa Group (Paleogene to Upper Miocene) and the Murracha Group (probable upper Tortonian to Piacenzian) (Cunha, 1992, 1996). The older group, mainly made up of arkoses, was deposited by an extensive fluvial drainage system in the Lower Tejo Tertiary basin. The younger group, predominantly consisting of coarse siliciclastic deposits, represents the sedimentary response to uplift phases of the Portuguese Central Cordillera. During the late Tortonian to Zanclean, the Lower Tejo basin was endorheic and alluvial fan sedimentation was present along tectonic scarps. An exorheic drainage system was only developed at the transition to the more humid conditions of the Piacenzian, when the ancestral Tejo river became a gravelly braided river with abundant bed load (Cunha et al., 1993). The Falagueira Formation, the last sedimentary episode of the Murracha Group, represents the beginning of an Atlantic fluvial system that captured the drainage network of the Madrid Tertiary Basin (Cunha et al., 1993; Pérez-González, 1994). In the study area, the Falagueira Formation is about $10 \mathrm{~m}$-thick and indicates that the ancestral Tejo river flowed over an extensive alluvial plain, up to $12 \mathrm{~km}$ wide. The unit is made up of quartz arenites and clast-supported conglomerates of quartzite (ca. 80\%) and quartz, with an average of the largest 10 clasts (MPS) of $25 \mathrm{~cm}$. Intense

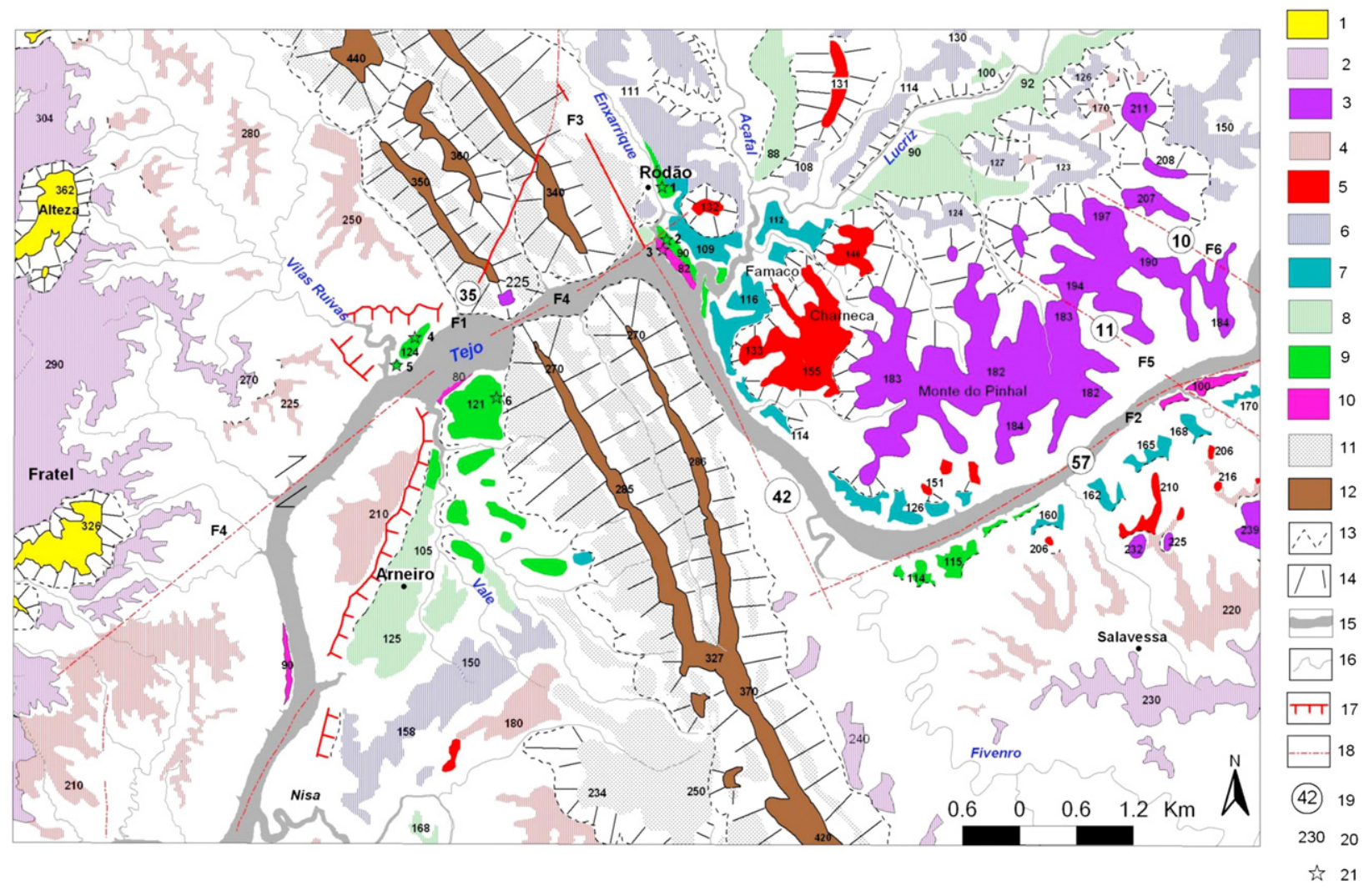

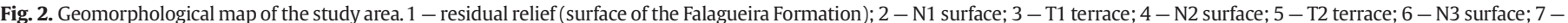

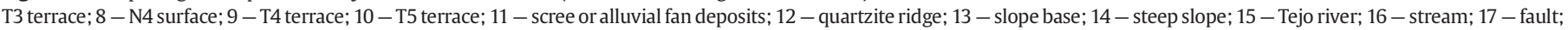

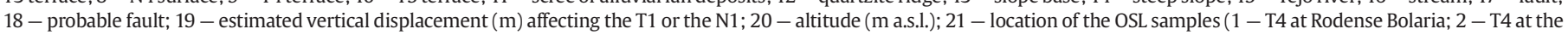
Enxarrique stream mouth; 3 - T5 at the Enxarrique stream mouth; 4 - T4 at Vilas Ruivas; 5 - T4 at the Vilas Ruivas stream mouth; 6 - T4 at Arneiro). 
kaolinization and hydromorphism are typical, reflecting a humid and hot climate and important drainage. During the following incision stage, deep valleys were excavated and, in tectonic depressions such as the Ródão graben, terrace staircases have developed.

\subsection{Tectonic structures}

The area is located in the Hesperian Massif, a strongly fractured morpho-structural unit of the Iberian Peninsula. Late-Variscan NNESSW, NE-SW, NW-SE and N-S trending faults were reactivated during the late Cenozoic by a maximum horizontal compressive stress trending NW-SE to WNW-ESE (Ribeiro et al., 1996). The main regional structure is the Ponsul fault, trending NE-SW, with a total length of $120 \mathrm{~km}$ and a maximum left lateral offset of around $1.5 \mathrm{~km}$. This structure was strongly reactivated during the late Tortonian to early Pliocene (Cunha, 1996; Sequeira et al., 1997) but evidence of some Plio-Quaternary reactivation was found at several places (Dias and Cabral, 1989). The fault gave rise to a large scarp, well exposed at the north and northwest sides of the Ródão graben. The actual morphological expression of the scarp (ca. $170 \mathrm{~m}$ ) results from partial exhumation by erosion of the Tertiary sediments. This can be inferred by the transverse drainage of one reach of the Ponsul river, a $7 \mathrm{~km}$ stretch of which sits on the uplifted block near Idanha-à-Nova (Ribeiro, 1939, 1943a) and by the transverse drainage of the Tejo river, also superimposed onto the Ponsul-Arneiro hanging fault wall (Ribeiro, 1943b) (F1 fault on Fig. 2). In the study area, some active faults were described by Cunha et al. (2005): a) the SW-NE Tejo reach fault (F2); the SSE-NNW Tejo reach fault (F3) and the Tejo gorge fault, trending NE-SW (F4; Fig. 2). Vertical displacements along these faults, affecting the drainage and the incision, will be described later.

\subsection{Relief}

The regional relief is dominated by elongate NW-SE resistant quartzite ridges (inselbergs), with altitudes of more than $500 \mathrm{~m}$, crossed by the Tejo river in a gorge "Portas do Ródão". Below the quartzite ridges, an extensive but fragmented Paleogene planation surface is developed at an altitude of ca. $300 \mathrm{~m}$ in the areas of metagreywackes/slates or granites. Within the Ródão depression this surface remains buried by Tertiary sediments.

The altitude of the lower segments of the quartzite ridges ( $270 \mathrm{~m}$ ) and the altitude of the Falagueira Formation remnants (300 to $362 \mathrm{~m}$ ) indicates that the ancestral Tejo river overlay these ridges and the hanging wall of the Ponsul fault (Ribeiro, 1943b).

The highest and oldest terrace (T1) and a planation surface (Fratel Level - N1) developed onto the basement are incised by between 35 and $50 \mathrm{~m}$ below the top of the Falagueira Formation and are extensively represented in the area (Cunha and Martins, 2000). The younger terraces and coeval erosion surfaces are incised by between 14 and $51 \mathrm{~m}$ below the previous terrace, and they will be described below.

\section{The Tejo river terraces in the Portuguese reach I}

Along the Tejo valley in the Portuguese reach I (Fig. 1), from the Spanish border to the Ponsul fault, four terrace levels have been previously identified and mapped (Cunha et al., 2005). However, more detailed field-work and dating have since shown that the lower and younger terrace may locally be made up of two levels, the upper one of which is a narrow strip. In the following paragraphs, the main characteristics of the terraces in the Monte do Pinhal-Enxarrique (Table 1) and in the Vilas Ruivas-Arneiro areas will be described (Figs. 2, 3, 4 and 5) in order to provide a context for the dating results.

The Monte do Pinhal terrace (T1) forms an extensive plateau at $183 \mathrm{~m}$ above sea level (a.s.l.; $117 \mathrm{~m}$ above the modern river bed - m.r.b.). T1 is $~ 13 \mathrm{~m}$ m-thick, and is made up of massive clast-supported gravel-boulder conglomerates, with poor to moderate sorting. The clasts are sub-rounded to rounded, with $\mathrm{MPS}=32 \mathrm{~cm}$, of quartzite (90\%) and white quartz, showing a red patina (iron oxides).

The Monte da Charneca terrace (T2), developed at $155 \mathrm{~m}$ a.s.l. (89 m above m.r.b.) but with a lower surface at $133 \mathrm{~m}$ a.s.l., seems to be a complex terrace on the right side of the Tejo river. This terrace is $\sim 23 \mathrm{~m}$-thick, consisting of massive clast-supported gravel-boulder conglomerates with some $0.5 \mathrm{~m}$-thick coarse sandstones lenses. The sorting is poor to very poor, due to the presence of a red sandy-silty matrix. The clasts are sub-rounded to rounded, with MPS $=24 \mathrm{~cm}$, of quartzite (78\%) and white quartz.

The Monte do Famaco terrace (T3), at $116 \mathrm{~m}$ a.s.l. (50 m above m.r.b.) can be readily identified close the Açafal stream mouth, and followed upstream as a narrow strip along the Tejo right bank. More upstream, on the left bank, it is identified by the remains of a strath (160$170 \mathrm{~m}$ a.s.l.). The T3 terrace is made up of a $1 \mathrm{~m}$-thick clast-supported gravel-boulder conglomerate, with poor sorting. The clasts are subrounded, with MPS $=32 \mathrm{~cm}$, of quartzite (75\%), white quartz and rare slates/metagreywackes. At the Monte do Famaco site, thirty-four rolled

Table 1

Summary of key geological and geomorphological attributes for the Monte do Pinhal-Enxarrique terrace staircase

\begin{tabular}{|c|c|c|c|c|c|c|}
\hline Level & Typology & $\begin{array}{l}\text { Previous incision } \\
\text { episode }\end{array}$ & Thickness & Altitude & Sedimentology & Lithic industries in situ \\
\hline $\begin{array}{l}\text { T1 } \\
\text { Monte do } \\
\text { Pinhal }\end{array}$ & Terrace & $\begin{array}{l}73 \mathrm{~m}(24-170 \mathrm{~m}) \text {, } \\
\text { below the Falgueira Fm. }\end{array}$ & $13 \mathrm{~m}$ & $\begin{array}{l}183 \mathrm{~m} \text { a.s.l. } \\
(117 \mathrm{~m} \text { a.r.b) }\end{array}$ & $\begin{array}{l}\text { - Massive clast-supported gravel-boulder conglomerates; poor } \\
\text { to moderate sorting; } \\
\text { - Sub-rounded to rounded clasts of quartzite (90\%) and quartz; } \\
\text { MPS }=32 \mathrm{~cm} \text {. }\end{array}$ & - \\
\hline $\begin{array}{l}\text { T2 } \\
\text { Monte da } \\
\text { Charneca }\end{array}$ & Terrace & $51 \mathrm{~m}(18-132 \mathrm{~m})$ & $23 \mathrm{~m}$ & $\begin{array}{l}155 \mathrm{~m} \text { a.s.l. } \\
\text { (89 } \mathrm{m} \text { a.r.b) }\end{array}$ & $\begin{array}{l}\text { - Massive clast-sup. gravel-boulder congl., with } 0.5 \text { m-thick coarse } \\
\text { sandstone lenses; poor sorting; } \\
\text { - Sub-rounded to rounded clasts of quartzite ( } 78 \% \text { ) and quartz; } \\
\text { MPS }=24 \mathrm{~cm} \text {. }\end{array}$ & - \\
\hline $\begin{array}{l}\text { T3 } \\
\text { Monte do } \\
\text { Famaco }\end{array}$ & $\begin{array}{l}\text { Terrace and } \\
\text { strath }\end{array}$ & $47 \mathrm{~m}(15-108 \mathrm{~m})$ & $1 \mathrm{~m}$ & $\begin{array}{l}109 \mathrm{~m} \text { a.s.l. } \\
(43 \mathrm{~m} \text { a.r.b) }\end{array}$ & $\begin{array}{l}\text { - Massive clast-sup. gravel-boulder congl.; poor sorting; } \\
\text { - Sub-rounded clasts of quartzite (75\%), quartz and rare slates/ } \\
\text { metagreywackes; MPS=32 cm. }\end{array}$ & $\begin{array}{l}\text { Middle Acheulian } \\
\text { (Lower Palaeolithic) }\end{array}$ \\
\hline $\begin{array}{l}\text { T4 } \\
\text { Capela da } \\
\text { Senhora da } \\
\text { Alagada }\end{array}$ & Terrace & $27 \mathrm{~m}(19-82 \mathrm{~m})$ & $8 \mathrm{~m}$ & $\begin{array}{l}90 \mathrm{~m} \text { a.s.l. } \\
(24 \mathrm{~m} \text { a.r.b) }\end{array}$ & $\begin{array}{l}\text { - Fine sandstones with pedogenic calcareous concretions (probable } \\
\text { conglomeratic base not exposed). }\end{array}$ & $\begin{array}{l}\text { Mousterian (Middle } \\
\text { Palaeolithic) at the top }\end{array}$ \\
\hline $\begin{array}{l}\text { T5 } \\
\text { Foz do } \\
\text { Enxarrique }\end{array}$ & Terrace & $14 \mathrm{~m}(90-76 \mathrm{~m})$ & $6 \mathrm{~m}$ & $\begin{array}{l}82 \mathrm{~m} \text { a.s.l. } \\
(16 \mathrm{~m} \text { a.r.b) }\end{array}$ & $\begin{array}{l}\text { - A basal } 0.5 \mathrm{~m} \text {-thick massive, clast-sup. boulder congl.; } \\
\text { - Upper } 5 \mathrm{~m} \text { of very fine sandstones with calcareous concretions; } \\
\text { - Sub-rounded clasts of quartzite and slates/metagreywackes; } \\
\text { MPS=31 cm; }\end{array}$ & $\begin{array}{l}\text { Late Mousterian (late } \\
\text { Middle Palaeolithic) }\end{array}$ \\
\hline $\begin{array}{l}\text { Modern } \\
\text { river bed }\end{array}$ & $\begin{array}{l}\text { Alluvium and } \\
\text { rocky bed }\end{array}$ & $16 \mathrm{~m}(2-66 \mathrm{~m})$ & $0-4 \mathrm{~m}$ & $66 \mathrm{~m}$ & - Pebbly to boulder gravel & \\
\hline
\end{tabular}




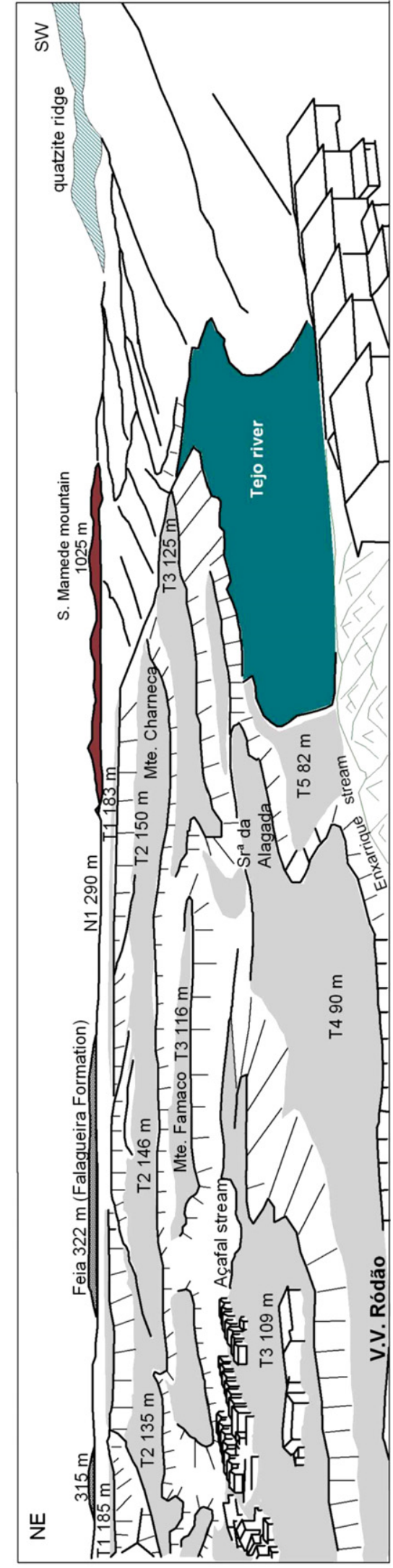

quartzite artifacts have been found in the conglomerate and attributed to the early middle Acheulian (Lower Palaeolithic) (Raposo, 1987). In a colluvium at the top of the terrace, $\sim 1500$ middle Acheulian quartzite artifacts - bifaces, cleavers, scrapers, etc. - have been collected, some showing evidence of wind abrasion but none indicating later fluvial transport.

The Capela da Senhora da Alagada terrace (T4), forms a very narrow constructional bench at ca. $90 \mathrm{~m}$ a.s.l. ( $24 \mathrm{~m}$ above m.r.b.) on the Tejo right bank, between the mouths of the Açafal and Enxarrique streams. The upper $4 \mathrm{~m}$ consists of fine sandstones (rich in quartz and muscovite), with thin levels of pedogenic calcareous concretions interpreted as fossil riparian root horizons. The lower part of T4 is covered by T5 deposits. In T4 and in a related colluvium, Mousterian artifacts (Middle Palaeolithic) have been found in situ. Immediately downstream of the quartzite gorge, the terrace is located at $124 \mathrm{~m}$ a.s.l. (59 $\mathrm{m}$ above m.r.b) on the right bank (near the Vilas Ruivas stream mouth) and at $121 \mathrm{~m}$ a.s.l. on the left bank (Arneiro). On the right bank, the T4 sedimentary sequence is made up of (Fig. 6): a) a 2 to 0.5 m-thick clast-supported boulder conglomerate (MPS $=42 \mathrm{~cm}$ ); b) $2-2.5 \mathrm{~m}$ of a pebbly medium sandstone with some planar cross stratifications and cobble channel pavements; this has yielded six rolled Acheulian type artifacts (Raposo and Silva, 1981; Raposo, 1987); c) a 1 to 0.5 m-thick siltite bed containing Mousterian artifacts (Raposo, 1995a), and; d) an upper $\sim 4 \mathrm{~m}$-thick clast-supported boulder conglomerate, massive and with MPS $=27 \mathrm{~cm}$. On the left bank (Arneiro), the sequence is thicker $(\sim 15 \mathrm{~m})$ and consists of $2 \mathrm{~m}$ of a basal sandy conglomerate, $4-10 \mathrm{~m}$ of massive coarse sandstones and an upper 0.2 to $8 \mathrm{~m}$-thick clastsupported gravel-boulder conglomerate (MPS $=40 \mathrm{~cm}$ ).

The Foz do Enxarrique terrace - T5 forms a constructional bench at $82 \mathrm{~m}$ a.s.l. (16 $\mathrm{m}$ above m.r.b.) on the Tejo right bank, between the mouths of the Açafal and Enxarrique streams. The T5 terrace is $6 \mathrm{~m} \mathrm{~m}$ thick. The base is a massive, clast-supported boulder conglomerate, 0.5 to $1 \mathrm{~m}$-thick and containing sub-rounded clasts, with MPS $=31 \mathrm{~cm}$, of quartzite, white quartz and metagreywackes/slates. The upper $5 \mathrm{~m}$ are white brown massive very fine sandstones (rich in quartz and muscovite) and coarse siltites, with some thin levels of pedogenic calcareous concretions. A 5 to $20 \mathrm{~cm}$-thick level at the base of the fine sandstones provided a rich in situ late Mousterian industry (Raposo, $2000,2002)$ - some ten thousand artifacts of quartzite $-67 \%$, quartz $23 \%$, and some flint - in association with abundant ( $\sim 800)$ fossils of mammals (Cervus elaphus - $27 \%$ of the total number of fossil remains, Equus caballus $-18 \%$, Bos primigenius $-1.2 \%$, Oryctolagus sp. $-2 \%$, Elephas antiquus - $0.7 \%$ and Vulpes vulpes - 0.1\%), birds and fish (Raposo et al., 1985; Raposo, 1987; Brugal and Raposo, 1999).

The present Tejo valley floor is at an altitude of 66 m.a.s.l. and the alluvium consists of some pebbly to boulder gravel.

The resistant quartzite ridges have promoted aggradation upstream of the gorge, where the river was easily able to enlarge the valley into the soft Tertiary sediments. The coarse-grained nature and poor sorting of the $\mathrm{T} 1, \mathrm{~T} 2$ and $\mathrm{T} 3$ sediments suggest transport as bed load with a high sediment to water ratio within a high-energy fluvial system. The downcutting into the Paleozoic basement explains the generally small representation of the $\mathrm{T} 4$ and $\mathrm{T} 5$. The terraces are restricted mainly to the confluences of the Açafal and Enxarrique streams where they enter against the flow of the Tejo river, leading to the local predominance of overbank fines.

The large Tejo valley between the quartzite gorge and the PonsulArneiro hanging wall fault, cut into the soft Tertiary arkoses, was also favourable for T4 aggradation.

\section{Fluvial control by local tectonics}

Geomorphological evidence for local tectonic control of drainage arises from interpretation of asymmetric valley and drainage patterns, fault scarps, tectonic lineaments, fracture-controlled valleys, and vertical displacement of planation surfaces and terraces (Cunha 

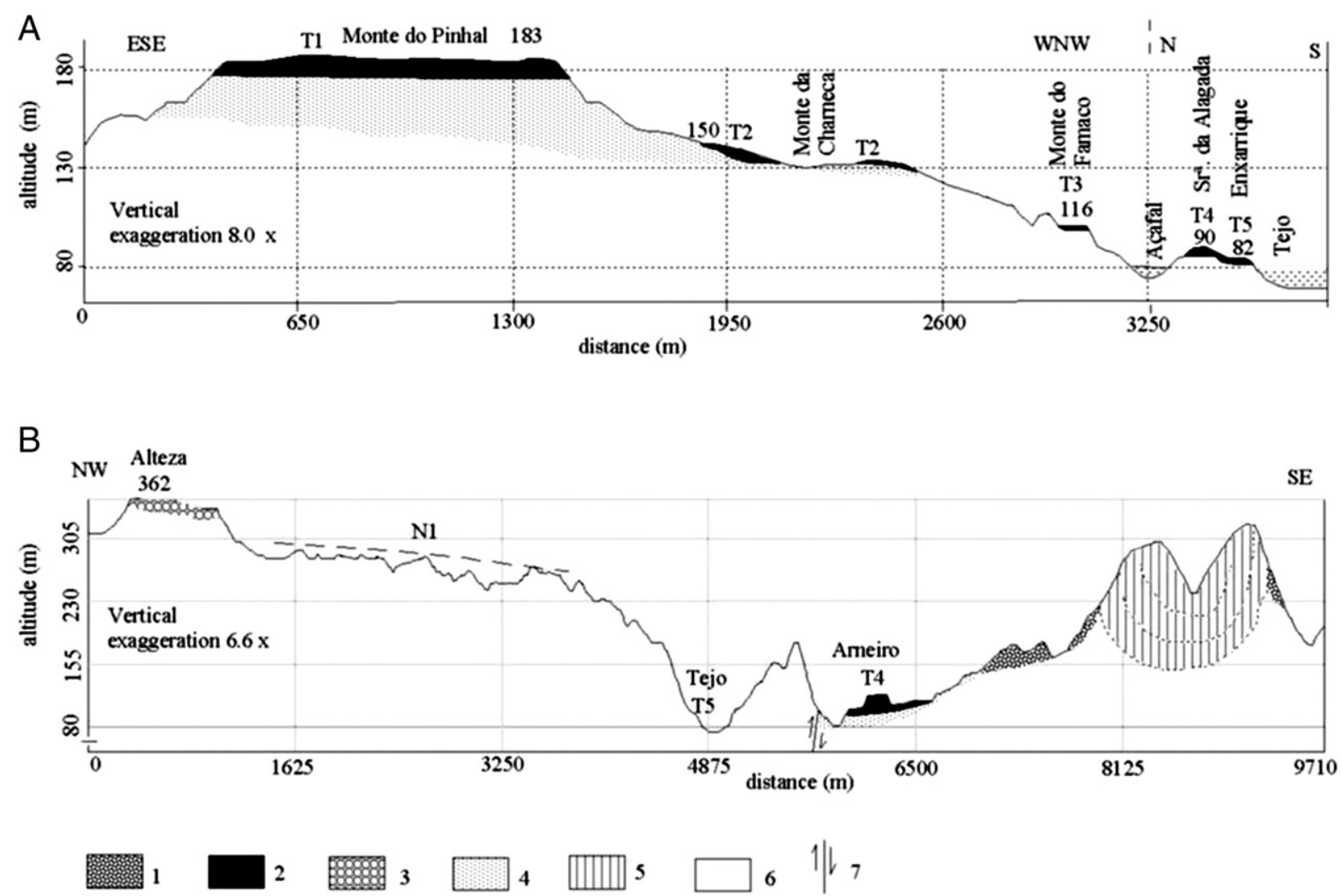

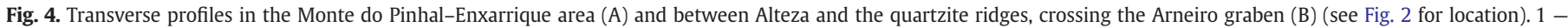

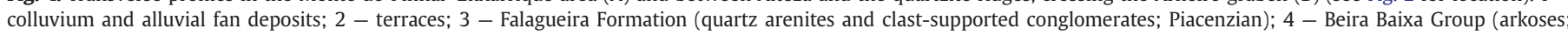
Paleogene); 5 - quartzites and slates (Ordovician); 6 - slates and metagreywackes (Late Precambrian and Cambrian); 7 - fault.

et al., 2005). In the study area, the main faults actively controlling the Tejo drainage are considered to be (Fig. 2):

- The Ponsul-Arneiro fault (F1), trending NNE-SSW, providing relatively greater uplift of the western block (vertical displacement: $\mathrm{N} 1-35 \mathrm{~m}$; N2 - $30 \mathrm{~m}$; T5 - ca. $10 \mathrm{~m}$ ). The T5 displacement was measured between the strath terrace $(90 \mathrm{~m})$ on the convex bank of the Tejo, southwest of Arneiro, and the narrow fill terrace $(80 \mathrm{~m})$ on the opposite bank, north of Arneiro.

- A probable fault (F2) controlling the valley of the local SW-NE Tejo reach. This fault displaces all the terraces (the southern block is uplifted; vertical displacement: T1 - 57 m; T2 - 55 m; T3 - 34 m; T4 - ca. 24 m; T5 - ca. 18 m).

- A probable SSE-NNW fault (F3), following the line of the Tejo valley until the entrance to the quartzite gorge (Dias and Cabral, 1989; Cunha et al., 2005). The alignment of this fault should correspond to the $\mathrm{N} 20^{\circ} \mathrm{W}, 45^{\circ} \mathrm{SW}$ reverse fault observed in a recent excavation inside the small town of Vila Velha de Ródão (Fig. 7). The outcrop shows the metamorphic basement thrust over the Cenozoic, here composed of angular to sub-rounded blocks of quartzite (not weathered) and beds of green siltite. This fault may be responsible for the vertical displacement of ca. $42 \mathrm{~m}$ of the T1

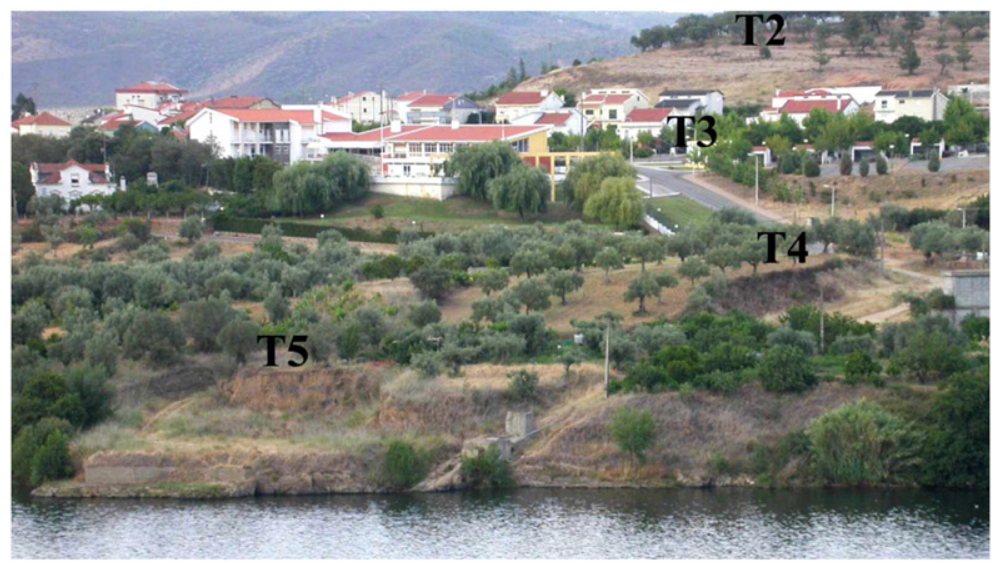

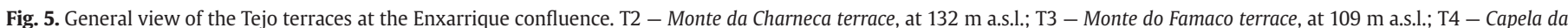

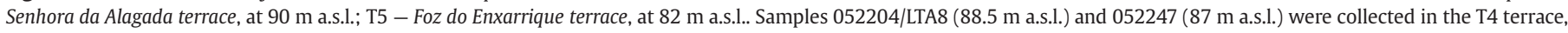

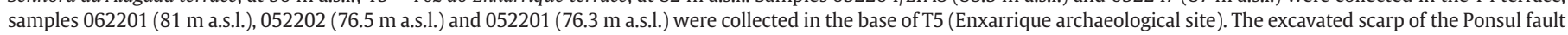
can be seen in the upper left corner. 


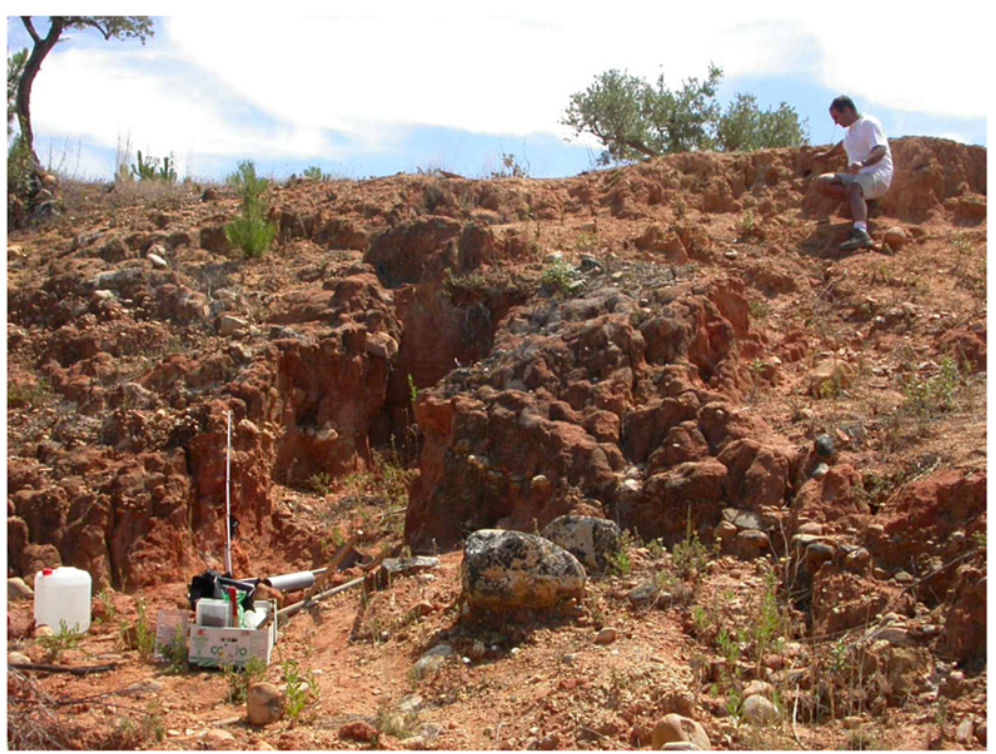

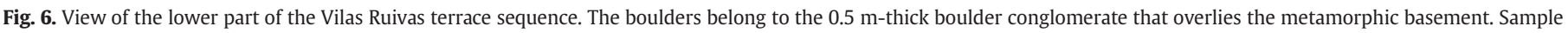

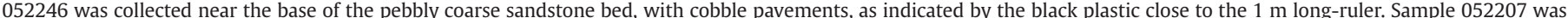

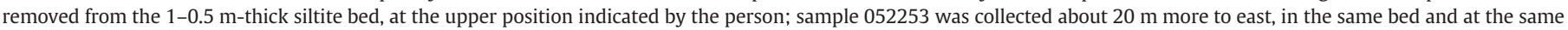
location as samples VRU1 and VRU2. This photograph does not show the upper part of the terrace sequence, a 4 m-thick conglomerate.

terrace (at $225 \mathrm{~m}$ a.s.l on the right bank of the quartzite gorge and at $183 \mathrm{~m}$ a.s.l. at Monte do Pinhal) and the $31 \mathrm{~m}$ displacement of T4 (at $90 \mathrm{~m}$ a.s.l. near the Enxarrique stream, upstream, and $121 \mathrm{~m}$ at Arneiro, downstream).

- The suspected NE-SW strike-slip fault (F4), along the asymmetric valley of the Lucriz stream, passing along the quartzitic gorge. This fault is probably represented in the outcrop located in the eastern sector of Vila Velha de Ródão (Senhora da Alagada urbanization). The fault plane $\left(\mathrm{N} 42^{\circ} \mathrm{E}, 85^{\circ} \mathrm{NW}\right)$ appears to displace Tertiary sediments and exhibit slickensides with a $28^{\circ} \mathrm{SW}$ pitch. This indicates a right-lateral oblique strike-slip fault, probably activated by a maximum compression along WNW-ESE (Cunha et al., 2005).

In summary, the complexity of these small fault-bounded blocks has resulted in unequal tectonic vertical movements in several sectors (Fig. 2) and accounts for the considerable differences in altitude of the several terrace levels in adjacent reaches. These differences are greatest in the oldest terraces, suggesting cumulative fault displacement. The faults referred to above are also responsible for the different altitudes of the same terrace on opposite banks of the Tejo river. This is particularly evident when comparing the Salavessa and Monte do Pinhal sectors (Fig. 2).

\section{Dating methods}

\subsection{Field techniques}

The geomorphological characterization of the Ródão area made use of 1:24,000 aerial orthophotos and a digital elevation model (DEM) based on a 1:25,000 topographic database, followed by detailed field surveying, mapping and outcrop description (Cunha et al., 2005). For the present study, complementary field-work was undertaken and sediment samples were collected for luminescence dating. The sampling strategy was to collect from the base and top of each terrace deposit, but only the two lower terraces provided lithologies (sandstones and siltites) suitable for luminescence dating. Each sample was collected in a light-safe tube, together with some additional material in a waterproof plastic bag for later laboratory analysis of water content, grain size and composition.

\subsection{Geochronological techniques and approaches}

Thermoluminescence (TL) dating and its counterpart, optically stimulated luminescence (OSL), are techniques for measuring the time

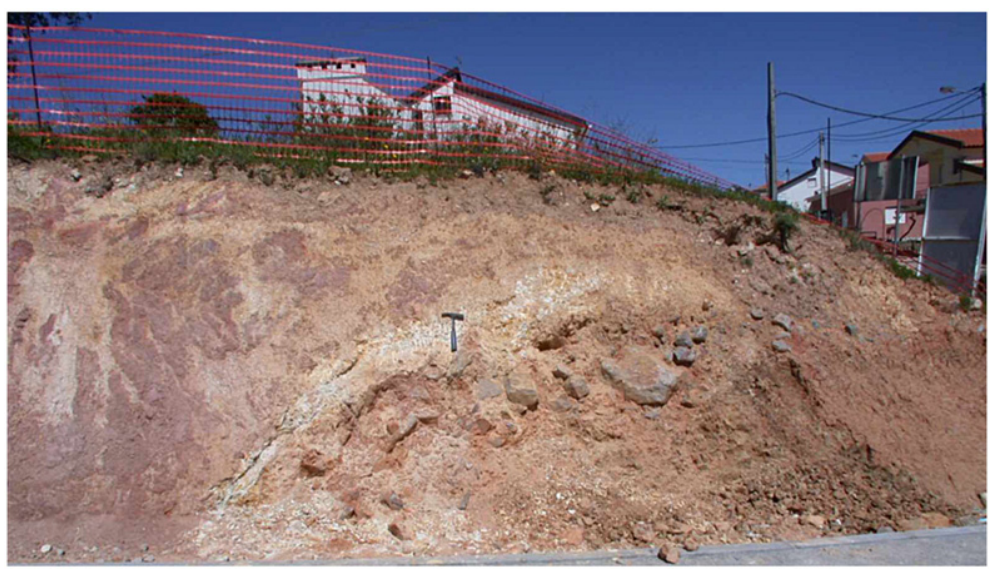

Fig. 7. Outcrop oriented E-W, at Vila Velha de Ródão, showing the metamorphic basement thrusting the Cenozoic. The hammer indicates the fault plane. 
Table 2

Summary of thermoluminescence dating results

\begin{tabular}{|c|c|c|c|c|c|c|c|}
\hline Laboratory code & Site name & Altitude (m) & Terrace level & Grain size & Dose rate $(\mathrm{Gy} / \mathrm{ka})$ & $D_{\mathrm{e}}(\mathrm{Gy})$ & Corrected age (ka) \\
\hline LTA8 & Enxarrique stream mouth & 88.5 & $\mathrm{~T} 4-\mathrm{top}$ & Very fine sand & $4.26 \pm 0.19$ & $500 \pm 20$ & $93+20 /-13$ \\
\hline VRU1 & Vilas Ruivas (Tejo river right bank) & 118 & T4 - middle & Silt & 6.81 & $500 \pm 200$ & $70+40 /-30$ \\
\hline VRU2 & Vilas Ruivas (Tejo river right bank) & 118 & T4 - middle & Silt & 6.53 & $350 \pm 90$ & $51+13 /-12$ \\
\hline
\end{tabular}

elapsed since sedimentary grains of quartz or feldspars were last exposed to daylight (Duller, 2004). The main difference which distinguishes the two methods is the mean of stimulating the signal from the sediment: TL uses heat (up to $500{ }^{\circ} \mathrm{C}$ ) and OSL employs intense narrow-band light from e.g. a light emitting diode array.

For TL dating, a portable gamma spectrometer was used in the field to estimate the sediment dose rate and thick source alpha counting was used to measure the alpha contribution (Table 2). Carbonates were removed with dilute $\mathrm{HCl}$ and the $2-10 \mu \mathrm{m}$ grains were mounted on a $\sim 10 \mathrm{~mm}$ diameter planchet. TL was measured in the UV through a Schott UG11 filter. The signals were integrated between 280 and $300{ }^{\circ} \mathrm{C}$. Equivalent doses were obtained by a multiple aliquots regenerative protocol (Wintle, 1997). A second glow measurement was employed to normalise the luminescence response of every aliquot.

For OSL dating, radionuclide concentrations were measured by high-resolution gamma spectrometry (Murray et al., 1987; Olley et al., 1996); the results are summarised in Table 3. To determine the internal dose rate from ${ }^{40} \mathrm{~K}$ and ${ }^{87} \mathrm{Rb}$ (in K-feldspar) we assumed a conservative estimate of $12.0 \pm 0.5 \%$ and $400 \pm 100 \mathrm{ppm}$, respectively, following the recommendation of Huntley and Baril (1997) and Huntley and Hancock (2001). All further processing took place under subdued red light. Wet sieving was used to separate the $180-250 \mu \mathrm{m}$ grain size, which was then acid treated using $\mathrm{HCl}(10 \%)$ and $\mathrm{H}_{2} \mathrm{O}_{2}(10 \%)$ to remove carbonates and organic matter, respectively. K-feldspar $\left(<2.58 \mathrm{~g} / \mathrm{cm}^{3}\right)$ was separated using a heavy liquid solution of sodium polytungstate. The outer layer of K-feldspar grains was etched with diluted $\mathrm{HF}$ (10\%, $40 \mathrm{~min})$, to minimise any contribution from external alpha particles to the dose rate. Finally, $\mathrm{HCl}(10 \%)$ was again used to dissolve any remaining soluble fluorides.

OSL measurements were performed on a Risø TL/DA-15 reader (Bøtter-Jensen et al., 2003). Luminescence was filtered by a combination of Schott BG39, Corning 7-59 and Schott GG400. The singlealiquot regenerative-dose (SAR) procedure was applied to measure the equivalent dose, $D_{\mathrm{e}}$ (Murray and Wintle, 2000). Identical heat treatments $\left(250{ }^{\circ} \mathrm{C}\right.$ for $60 \mathrm{~s}$ ) for both dose and test dose (Auclair et al., 2003; Huot and Lamothe, 2003) were employed. Optical stimulation was with infrared diodes $(880 \mathrm{~nm})$ for $100 \mathrm{~s}$ at $50{ }^{\circ} \mathrm{C}$. Further technical details and observations are provided when using the SAR protocol (Murray and Wintle, 2000; Murray and Olley 2002).

\section{Results of the luminescence dating}

Thermoluminescence ages derived in the manner used here are known to underestimate the event of interest, due to a non-thermal mechanism with a mean life of approximately $100 \mathrm{ka}$, and have been corrected to compensate for this phenomenon (Debenham, 1985) (Table 2).

Infrared stimulated luminescence dating of K-feldspar was performed on 13 terrace samples. On each sample the OSL measurements were made on 8-24 aliquots, each containing about 100 grains. The natural luminescence was well below the saturation level allowing us to precisely measure the equivalent dose from all of our samples. Recycling ratios were close to unity, indicating that the test doses successfully monitored changes in luminescence sensitivity throughout the measurement sequence. Dose recovery tests (Wintle and Murray, 2006) were also successful (mean ratio of measured to given dose of $0.98 \pm 0.02 ; n=84$ ), thus suggesting our SAR protocol is able to accurately determine doses given in the laboratory before any heating of the sample.
OSL ages, derived by dividing the equivalent doses $\left(D_{\mathrm{e}}\right)$ by the total dose rates, are summarised in Table 4 . It is likely that the OSL ages from K-feldspars underestimate the burial age because of anomalous fading (Huntley and Lamothe, 2001; Huntley and Lian, 2006). In anomalous fading, some trapped electrons leak out of traps (in particular those that give rise to the OSL signal) while the sediment is buried. Laboratory induced luminescence does not have the time to decay by the same relative amount as does the natural luminescence. Because $D_{\mathrm{e}}$ is measured essentially by taking the ratio of natural luminescence to that regenerated by a laboratory beta dose, measurements of equivalent doses are expected to underestimate the true burial dose. Our measurements of the rate of this anomalous fading also used the same SAR procedure as outlined above. Time delays were inserted after the heat treatment of the dose (Lx) and before the corresponding luminescence measurement (Auclair et al., 2003). An average value of " $g$ " (a measure of the fading rate) of $3.15 \pm 0.04 \% /$ decade $(n=143)$ was observed. This rate was used for fading corrections using the dose rate correction (DRC) of Lamothe et al. (2003) (Table 4). We are sceptical of the precision in our ages obtained from sediments with uncorrected $D_{\mathrm{e}}$ values $>500 \mathrm{~Gy}$. In these cases the DRC model puts the natural signals close to luminescence saturation, giving a minimum corrected $D_{\mathrm{e}}$ of about $1000 \mathrm{~Gy}$.

\section{Discussion of the luminescence dating results}

The OSL ages confirm the chronological sequence of terrace formations and agree with the age interpretation of the archaeological materials found in situ in the terraces: T5 - late Mousterian (late Middle Palaeolithic); T4 - Acheulian (Lower Palaeolithic) and Mousterian (Middle Palaeolithic) at the top; and T3 - middle Acheulian.

Taking into account the position in the sedimentary sequences of the corrected K-feldspar ages it is probable that the younger terraces have an age range of (Table 4 and Fig. 8): T5 - 31 to $40 \mathrm{ka}$; T4 - 100 to $\sim 280 \mathrm{ka}$; and T3 ->300 ka.

Sample 052202 gave an uncorrected age of $25.4 \pm 1.0 \mathrm{ka}$, clearly showing an age underestimation when compared with the U-series performed on three teeth from the same stratigraphic level (isochron plot resulting in an age of $33.6 \pm 0.5 \mathrm{ka}$ ) (Raposo, 1995b). The corrected age of $34.8 \pm 1.3 \mathrm{ka}$ is much closer to this value and helps to give confidence in the fading correction approach.

Table 3

Summary of radionuclide activities, water content and corresponding dose rates

\begin{tabular}{lccclll}
\hline $\begin{array}{l}\text { Laboratory } \\
\text { code }\end{array}$ & $\begin{array}{l}{ }^{238} \mathrm{U} \\
(\mathrm{Bq} / \mathrm{kg})\end{array}$ & $\begin{array}{l}{ }^{226} \mathrm{Ra} \\
(\mathrm{Bq} / \mathrm{kg})\end{array}$ & $\begin{array}{l}{ }^{232} \mathrm{Th} \\
(\mathrm{Bq} / \mathrm{kg})\end{array}$ & $\begin{array}{l}{ }^{40} \mathrm{~K} \\
(\mathrm{~Bq} / \mathrm{kg})\end{array}$ & $\begin{array}{l}\text { Water } \\
\text { content }(\%)\end{array}$ & $\begin{array}{l}\text { Dose rate } \\
(\mathrm{Gy} / \mathrm{ka})\end{array}$ \\
\hline 052208 & $19 \pm 6$ & $28 \pm 0.6$ & $30 \pm 0.6$ & $902 \pm 17$ & 25 & $3.91 \pm 0.12$ \\
052247 & $44 \pm 4$ & $49 \pm 0.6$ & $75 \pm 0.7$ & $765 \pm 8$ & 15 & $4.87 \pm 0.17$ \\
052204 & $52 \pm 4$ & $52 \pm 0.5$ & $76 \pm 0.7$ & $715 \pm 9$ & 15 & $4.81 \pm 0.17$ \\
052201 & $108 \pm 6$ & $109 \pm 1$ & $191 \pm 2$ & $784 \pm 19$ & 25 & $6.97 \pm 0.24$ \\
052202 & $89 \pm 6$ & $77 \pm 0.8$ & $98 \pm 0.9$ & $727 \pm 10$ & 25 & $4.95 \pm 0.17$ \\
062201 & $64 \pm 7$ & $68 \pm 0.9$ & $92 \pm 1$ & $764 \pm 14$ & 10 & $5.68 \pm 0.21$ \\
052246 & $27 \pm 4$ & $23 \pm 0.4$ & $28 \pm 0.5$ & $843 \pm 12$ & 10 & $4.21 \pm 0.15$ \\
052207 & $63 \pm 11$ & $70 \pm 2$ & $109 \pm 2$ & $621 \pm 33$ & 13 & $5.38 \pm 0.21$ \\
052253 & $69 \pm 8$ & $61 \pm 0.8$ & $96 \pm 1$ & $536 \pm 10$ & 10 & $5.00 \pm 0.19$ \\
062216 & $43 \pm 6$ & $36 \pm 0.6$ & $59 \pm 0.8$ & $734 \pm 12$ & 12 & $4.55 \pm 0.16$ \\
062217 & $45 \pm 5$ & $42 \pm 0.6$ & $67 \pm 0.7$ & $625 \pm 8$ & 18 & $4.23 \pm 0.14$ \\
062202 & $25 \pm 5$ & $28 \pm 0.5$ & $22 \pm 0.5$ & $843 \pm 14$ & 10 & $4.10 \pm 0.15$ \\
062203 & $18 \pm 5$ & $25 \pm 0.5$ & $27 \pm 0.5$ & $995 \pm 12$ & 8 & $4.64 \pm 0.17$ \\
\hline
\end{tabular}


Table 4

Summary of optically stimulated luminescence from K-feldspars

\begin{tabular}{|c|c|c|c|c|c|c|c|c|c|c|c|}
\hline $\begin{array}{l}\text { Field } \\
\text { code }\end{array}$ & $\begin{array}{l}\text { NLL laboratory } \\
\text { code }\end{array}$ & Site name & $\begin{array}{l}\text { Altitude } \\
(\mathrm{m})\end{array}$ & $\begin{array}{l}\text { Terrace } \\
\text { level }\end{array}$ & Grain size & $\begin{array}{l}\text { Dose recovery } \\
\text { (measured/applied) }^{a}\end{array}$ & $D_{\mathrm{e}}(\mathrm{Gy})$ & $n$ & $\begin{array}{l}\text { Dose rate } \\
(\mathrm{Gy} / \mathrm{ka})\end{array}$ & $\begin{array}{l}\text { OSL age } \\
(\mathrm{ka})^{\mathrm{b}}\end{array}$ & $\begin{array}{l}\text { Corrected } \\
\text { age (ka) }\end{array}$ \\
\hline$\overline{\text { PC9 }}$ & 052208 & $\begin{array}{l}\text { Rodense Bolaria (Enxarrique } \\
\text { stream) }\end{array}$ & 101 & $\mathrm{~T} 4$ - base & Silt & $1.01 \pm 0.02$ & $624 \pm 11$ & 12 & $4.1 \pm 0.1$ & $151 \pm 7$ & - \\
\hline ENXAR1 & 052247 & Enxarrique stream mouth & 87 & T4 - middle & $\begin{array}{l}\text { Very fine } \\
\text { sand }\end{array}$ & $1.05 \pm 0.01$ & $371 \pm 8$ & 17 & $4.9 \pm 0.2$ & $76 \pm 3$ & $125 \pm 7$ \\
\hline PC4 & 052204 & Enxarrique stream mouth & 88.5 & $\mathrm{~T} 4-$ top & $\begin{array}{l}\text { Very fine } \\
\text { sand }\end{array}$ & $0.95 \pm 0.01$ & $346 \pm 13$ & 8 & $4.8 \pm 0.2$ & $71 \pm 4$ & $136 \pm 10$ \\
\hline PC1 & 052201 & Enxarrique stream mouth & 76.3 & T5 - base & $\begin{array}{l}\text { Very fine } \\
\text { sand }\end{array}$ & $0.93 \pm 0.01$ & $184.7 \pm 3.3$ & 12 & $7.0 \pm 0.2$ & $26.5 \pm 1.2$ & $38.5 \pm 1.6$ \\
\hline PC2 & 052202 & Enxarrique stream mouth & 76.5 & T5 - base & $\begin{array}{l}\text { Very fine } \\
\text { sand }\end{array}$ & - & $125.9 \pm 0.9$ & 10 & $5.0 \pm 0.2$ & $25.4 \pm 1.0$ & $34.8 \pm 1.3$ \\
\hline ENXAR2 & 062201 & Enxarrique stream mouth & 81 & T5 - top & $\begin{array}{l}\text { Very fine } \\
\text { sand }\end{array}$ & $1.06 \pm 0.01$ & $120.7 \pm 1.3$ & 24 & $5.7 \pm 0.2$ & $21.3 \pm 0.9$ & $31.6 \pm 1.3$ \\
\hline VRU5 & 052246 & Vilas Ruivas (right bank) & 116 & $\mathrm{~T} 4$ - base & Coarse sand & $0.99 \pm 0.02$ & $636 \pm 21$ & 13 & $4.2 \pm 0.1$ & $151 \pm 8$ & $277 \pm 17$ \\
\hline PC8 & 052207 & Vilas Ruivas (right bank) & 118 & T4 - middle & Silt & $0.98 \pm 0.02$ & $349 \pm 13$ & 12 & $5.4 \pm 0.2$ & $65 \pm 4$ & $105 \pm 5$ \\
\hline VRU3 & 052253 & Vilas Ruivas (right bank) & 118 & T4 - middle & Silt & $0.96 \pm 0.01$ & $351 \pm 9$ & 12 & $5.0 \pm 0.2$ & $70 \pm 3$ & $113 \pm 6$ \\
\hline FVR1 & 062216 & Vilas Ruivas stream mouth & 90 & $\mathrm{~T} 4$ & Muddy sand & $1.03 \pm 0.01$ & $396 \pm 6$ & 20 & $4.5 \pm 0.2$ & $87 \pm 4$ & $151 \pm 6$ \\
\hline FVR2 & 062217 & Vilas Ruivas stream mouth & 88 & $\mathrm{~T} 4$ & Silt & $1.03 \pm 0.01$ & $463 \pm 11$ & 12 & $4.2 \pm 0.1$ & $109 \pm 5$ & - \\
\hline PARN1 & 062202 & Arneiro (left bank) & 105 & $\begin{array}{l}\mathrm{T} 4-\text { near } \\
\text { base }\end{array}$ & Medium sand & $0.99 \pm 0.00$ & $479 \pm 13$ & 12 & $4.1 \pm 0.2$ & $117 \pm 6$ & $209 \pm 11$ \\
\hline PARN2 & 062203 & Arneiro (left bank) & 128 & $\mathrm{~T} 4-$ top & Medium sand & $0.99 \pm 0.01$ & $371 \pm 12$ & 12 & $4.6 \pm 0.2$ & $80 \pm 4$ & $129 \pm 8$ \\
\hline
\end{tabular}

a Represents the average of 10-12 aliquots.

b Ages are considered as minimum estimates; see text for additional details.

Despite possible limitations in accuracy arising from the presence of anomalous fading, we suggest that any systematic error in age should be similar from one sample to another, since all mineral samples derive from the same drainage catchment. The sediment should contain a homogeneous mixture of K-feldspars, originating from the same geological source or mixture of sources. Hence, the associated effects of anomalous fading should be similar between samples, implying that sediment of the same age should provide comparable ages, whether uncorrected or corrected. There is evidence to support such a conclusion (e.g. Wolfe et al., 2002).

As it was stated before, $D_{\mathrm{e}}$ values $>500 \mathrm{~Gy}$, as measured in samples 052208 and 052246 , probably underestimate the true age, and we regard them here as only $>300 \mathrm{ka}$.

The fading corrected OSL ages have a tendency to be older than the corrected TL ages and have much higher precision. The discrepancy between the two sets of ages may reflect differences in the correction models employed by these two methods. For instance, the same 1-0.5 m m-thick siltite bed, at the middle part of the Vilas Ruivas terrace sequence, gave TL ages of $51+13 /-12$ ka and $70+40 /-30$ ka (samples VRU1 and VRU2), and OSL corrected feldspar ages of $105 \pm 5 \mathrm{ka}$ and $113 \pm 6 \mathrm{ka}$ (samples 052207 and 052253). Also, the same stratigraphic level at the Senhora da Alagada terrace (T4) provided a TL age of $93+20 /-13 \mathrm{ka}$ (sample LTA8) and an OSL corrected feldspar age of $136 \pm 10 \mathrm{ka}$ (sample 052204); the corrected age of sample 052247 , located $1.5 \mathrm{~m}$ below, is $125 \pm 7 \mathrm{ka}$.

Due to its altitude (121 to $124 \mathrm{~m}$ a.s.l.), the terrace at the Vilas RuivasArneiro area was previously correlated with the T3 (116 m a.s.l., Monte do Famaco). However, recent geomorphological mapping indicates that the Monte do Pinhal-Enxarrique area is less uplifted and the luminescence dating (Fig. 8) supports correlation with the T4 (90 $\mathrm{m}$ a.s.l.). If this is true, the vertical displacement of the T4 between these two areas is $\sim 30 \mathrm{~m}$.

\section{Estimation of aggradation and incision rates, and the interpretation of uplift}

The corrected OSL K-feldspar ages of the T4 and T5 indicate the following broad fluvial episodes: $\sim 10 \mathrm{~m}$ of aggradation from $\sim 280$ to

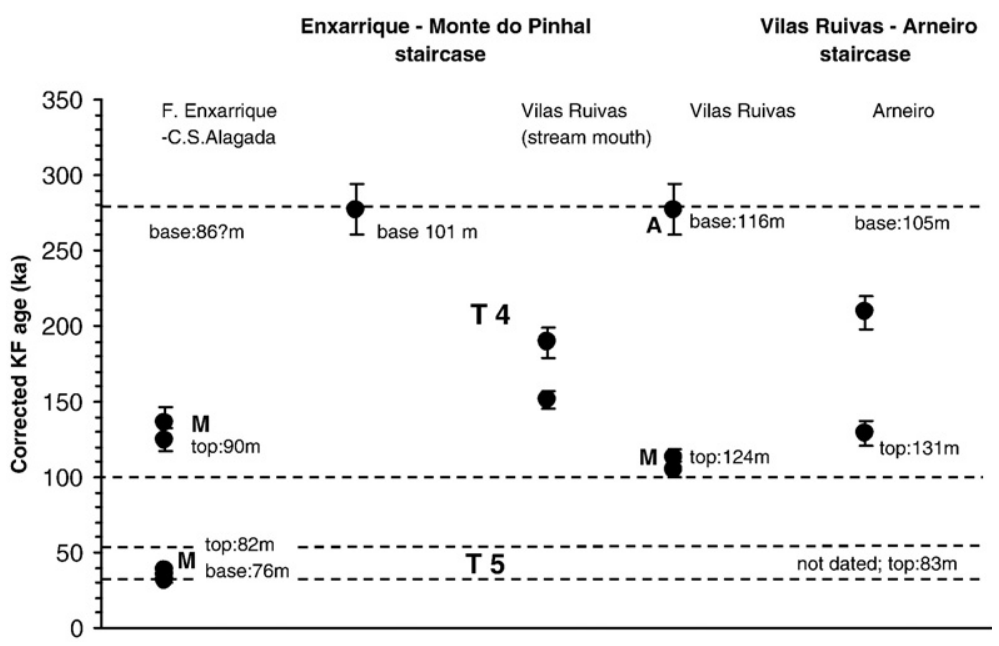

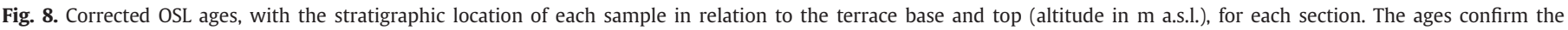

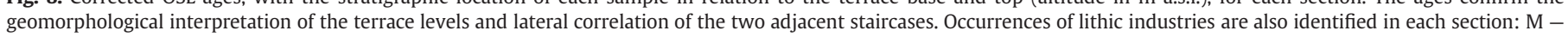
Mousterian; A - Acheulian. 
$100 \mathrm{ka}(0.06 \mathrm{~m} / \mathrm{ka}) ; 14 \mathrm{~m}$ of incision from 100 to $40 \mathrm{ka}(0.23 \mathrm{~m} / \mathrm{ka})$; $8 \mathrm{~m}$ of aggradation from 40 to $31 \mathrm{ka}(0.89 \mathrm{~m} / \mathrm{ka}) ; 16 \mathrm{~m}$ of incision during the last $31 \mathrm{ka}(0.52 \mathrm{~m} / \mathrm{ka})$.

According to Burbank and Anderson (2001), fluvial terraces etched into bedrock (strath terraces) record previous positions of an actively incising river; using the height of a strath above the modern river, if it is assumed that the strath resulted from erosion at or near the low point of the river channel, and if the elapsed time since the abandonment of the strath by the incision river is known, then long-term rates of bedrock incision can be calculated (e.g. Maddy, 1997; Maddy et al., 2000). These incision rates are, in turn, used as a proxy for rock-uplift rates (Merritts et al., 1994). For the Enxarrique-Monte do Pinhal staircase, time-averaged incision rates can be estimated using the following references: a) the $\sim 66 \mathrm{~m}$ a.s.l. surface corresponding to the modern Tejo bed; b) the T5 terrace surface, at $82 \mathrm{~m}$ a.s.l., $16 \mathrm{~m}$ above the river bed (a.r.b.), dated at $\sim 31 \mathrm{ka}$; c) the T4 terrace surface at $90 \mathrm{~m}$ a.s.l. (24 $\mathrm{m}$ a.r.b.), dated at $\sim 100 \mathrm{ka}$; and d) the probable position of the Falagueira Formation surface, at about $243 \mathrm{~m}$ a.s.l. (177 $\mathrm{m}$ a.r.b.), for which the probable age is estimated at $\sim 2.6 \mathrm{Ma}$, suggested by dating in the more distal sediments of this Atlantic sedimentary system (Cunha et al., 1993). Using these values, several time-averaged incision rates can be calculated: a) $0.52 \mathrm{~m} / \mathrm{ka}$ over the last $31 \mathrm{ka}(16 \mathrm{~m} / 31 \mathrm{ka})$; b) $0.24 \mathrm{~m} / \mathrm{ka}$ over the last $100 \mathrm{ka}(24 \mathrm{~m} / 100 \mathrm{ka}) ; \mathrm{c}) \sim 0.07 \mathrm{~m} / \mathrm{ka}$ estimated for the last 2.6 Ma (177 m/2600 ka) (Fig. 9). The decrease in the timeaveraged incision rate is not surprising, since pulses of uplift, which can be significant over short time-scales, average out over longer timescales with periods of quiescence. An estimate for the burial ages of the T3, T2 and T1 deposits was obtained by fitting a curve using the available age controls and the respective height of terrace surfaces above river bed: T3 at $\sim 470 \mathrm{ka}, \mathrm{T} 2$ at $\sim 1.2 \mathrm{Ma}$ and T1 at $\sim 1.6 \mathrm{Ma}$.

A similar approach can be made in the Vilas Ruivas-Arneiro area, downstream of the quartzitic gorge, using the following reference levels: a) the $\sim 65 \mathrm{~m}$ a.s.l. corresponding to the modern Tejo bed; $b$ ) the T4 surface at $124 \mathrm{~m}$ a.s.l., dated at $\sim 100 \mathrm{ka}$; c) the top of the Falagueira Formation, at $290 \mathrm{~m}$ a.s.l. ( 2.6 Ma). The corresponding time-averaged incision rates are: a) $0.56 \mathrm{~m} / \mathrm{ka}$ over the last $100 \mathrm{ka}$ (56 m/100 ka); b) $\sim 0.09 \mathrm{~m} / \mathrm{ka}$ estimated for the last $2.6 \mathrm{Ma}(225 \mathrm{~m} / 2600 \mathrm{ka})$.

Just downstream of the Ponsul-Arneiro fault (beginning of reach II), in the hanging wall, the Falagueira Formation surface is at $326 \mathrm{~m}$ a.s.l., the $\mathrm{N} 1$ surface at about $270 \mathrm{~m}$ a.s.l., the $\mathrm{N} 2$ surface at $225-210 \mathrm{~m}$ a.s.l., a small strath at $90 \mathrm{~m}$ a.s.l. (T5), and the river bed at $\sim 60 \mathrm{~m}$ a.s.l. A longterm incision rate of about $0.10 \mathrm{~m} / \mathrm{ka}$ is estimated for the last $2.6 \mathrm{Ma}$ (266 m/2.6 Ma).
The above estimates of time-averaged incision rates for the adjacent tectonic blocks crossed by the Tejo river are greater than those corresponding to the Enxarrique-Monte do Pinhal area because the equivalent fluvial geomorphic records are at higher altitude, thus indicating more uplift.

The long-term incision rates calculated for the Tejo reach I are similar to previous estimates (Cabral, 1995) for uplift in Central Portugal that reach rates of ca. $0.1 \mathrm{~m} / \mathrm{ka}$ for the last $3.5 \mathrm{Ma}$ and $0.2 \mathrm{~m} / \mathrm{ka}$ for the last 1.6 Ma near the coast and rather more in the upland areas (ca. 0.1 and $0.3 \mathrm{~m} / \mathrm{ka}$, respectively). A geodynamic model of activation of the Portuguese passive margin by horizontal compressive stress seems to be compatible with rates of this magnitude (Ribeiro et al., 1996).

Cloetingh et al. (1990) suggested that the increase in the Quaternary uplift rates of areas located around the edges of the North Atlantic basin is the result of major reorganization of spreading direction and rate. This occurred during the Pliocene along the Atlantic spreading system, leading to an increase in the intraplate tectonic stress.

Studies in lowland Europe, for example on the Thames, RhineMeuse (Maas), Loire-Allier and others (e.g. Van den Berg, 1996; Bridgland, 2000; Westaway et al., 2002, 2003; Brocard et al., 2003; Westaway, 2004; Wallinga et al., 2004) also used river terraces to calculate incision rate and infer uplift. As noted by Lancaster (2005), those studies indicate an average regional incision/uplift rate of 0.1 to $0.2 \mathrm{~m} / \mathrm{ka}$ during the Pleistocene, but the values vary significantly both geographically and temporally. For example, incision rates of the Rhine-Meuse system were interpreted to have increased since the late Pliocene from $0.03 \mathrm{~m} / \mathrm{ka}$ to $0.61 \mathrm{~m} / \mathrm{ka}$ (Bridgland, 2000).

For the genesis of the terraces examined here, Cunha et al. (2005) proposed a regional uplift event controlling one period of incision, followed by a period of valley enlargement and aggradation. Based on the obtained OSL dating, the intervals of incision can be estimated as: $\sim 470$ (?) to $\sim 280 \mathrm{ka} ; 100$ to $\sim 40 \mathrm{ka}$; and the last $31 \mathrm{ka}$. The youngest incision interval could also have been induced by a sea-level lowering (35 to $16 \mathrm{ka}$, oxygen isotope stage (OIS) 2; Pillans et al., 1998) but the previous period ( $\sim 100$ to $\sim 40 \mathrm{ka}$ ) was presumably determined by uplift; it does not correspond to any known low sea-level stand. It is also interesting to note that the age range obtained for the T4 terrace $(\sim 280$ to $100 \mathrm{ka}$ ) indicates a long aggradation period ( $180 \mathrm{ka})$, with no indication of the OIS 6 low sea-level stand, during which sea level was about $-120 \mathrm{~m}$ (at $\sim 140 \mathrm{ka}$ ). Climatic changes during the Quaternary (Shackleton and Opdyke, 1973) do not provide clear trends that might

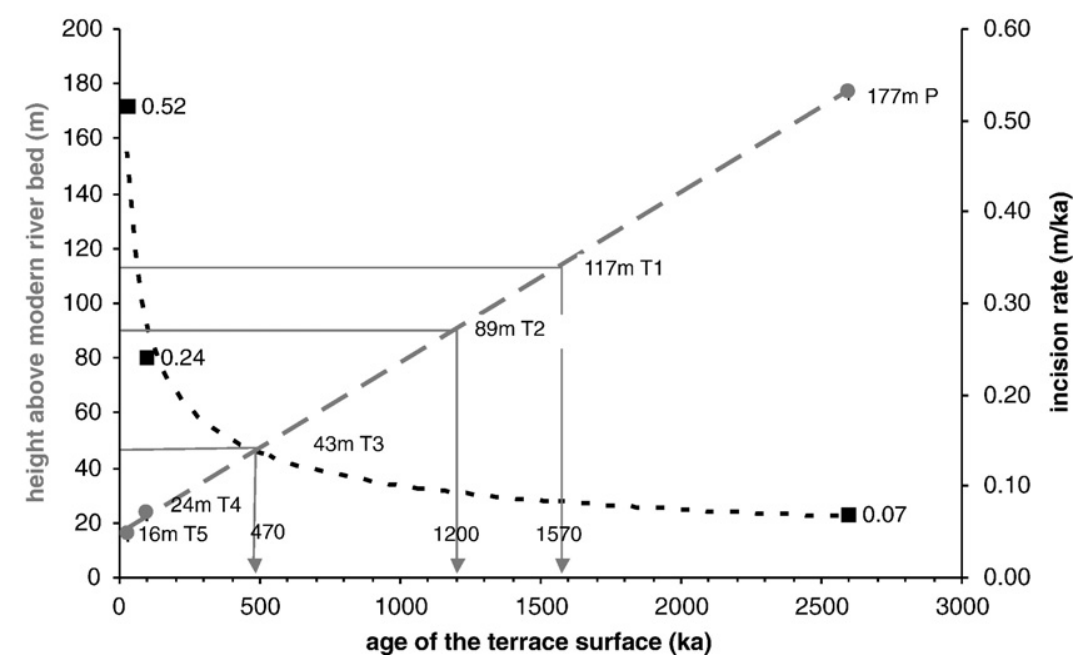

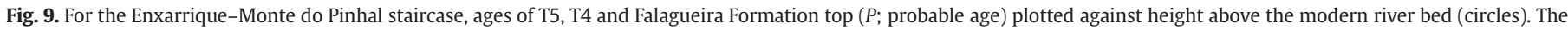

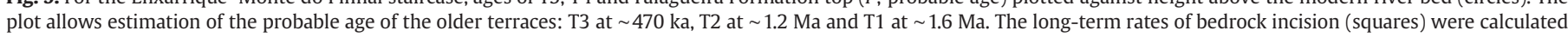
based on the height of the terrace above the modern river bed and the respective age. 
explain the formation of these terraces. Blum and Törnqvist (2000) have argued that one of the main difficulties in correlating terrace genesis with a climate control arises from the complexity of the climate change during the glacial-interglacial cycles; climate changes on temporal scales of $10^{3}$ and $10^{4} \mathrm{yr}$ are superimposed on the $100 \mathrm{ka}$ cycles. The debate between climate and tectonic models is also conditioned by the resolution of the existing dating methods and obtained ages.

\section{Conclusions}

Of the terrace levels distinguished in the more upstream Portuguese reach of the Tejo river, only the two lower levels were found to be suitable for OSL dating. The older terraces give ages beyond the range of our present luminescence dating methods. They need to be dated by other techniques, such as cosmogenic radionuclide profiling.

The high dose rates of the sediments ( 4.1 to $7.0 \mathrm{~Gy} / \mathrm{ka}$ ) prevented the use of OSL from quartz for all samples. However, infrared stimulated luminescence dating of K-feldspar (with anomalous fading correction) has provided important support for the geomorphological correlation of the terraces and interpretation of tectonic displacements. Taking into account the position of the corrected K-feldspar ages in the sedimentary sequences, it is probable that the younger terraces have an age range of: T5 -31 to $40 \mathrm{ka}$; T4 - 100 to $280 \mathrm{ka}$; and T3 $->300 \mathrm{ka}$. These ages provide an important contribution to the age interpretation of the archaeological materials found in situ in the terraces: T5 - late Mousterian (late Middle Palaeolithic); T4 Acheulian (Lower Palaeolithic) at the base and Mousterian (Middle Palaeolithic) at the top; and T3 - middle Acheulian.

Intervals of strath cutting occurred between: 0 to $31 \mathrm{ka} ; \sim 40$ to $\sim 100 \mathrm{ka}$; and $\sim 280$ to ?470 ka. These cannot readily be related to climate changes; although the youngest interval might have been induced by sea-level lowering (35 to $16 \mathrm{ka}$ ), the previous interval appears to have been controlled mainly by an episode of crustal uplift.

Fluvial terraces can be used to record the response of the river to differential uplift across faults. The time-averaged incision rate from the Rodão graben ( $\sim 0.07 \mathrm{~m} / \mathrm{ka}$ over the last $\sim 2.6 \mathrm{Ma})$ is smaller than those derived from the adjacent reaches (e.g. reach II, $\sim 0.10 \mathrm{~m} / \mathrm{ka}$ ). In those reaches, the Tejo has a narrow valley incised in the Variscan basement, partly because of the presence of resistant bedrock. The long-term incision rate calculated for the study area as a whole is similar to previous estimates for uplift in central Portugal and in lowland Europe.

The intensification of tectonically driven regional uplift has provided a steady forcing function causing overall incision of the Tejo river over the past $\sim 2.6 \mathrm{Ma}$. Higher frequency tectonic clustering, possibly coupled with climatically modulated variations in sediment flux and river discharge, are superimposed on this forcing function and have led to the creation of terraces. However, a full interpretation of the relative importance of climate or eustasy versus tectonics in terrace formation needs the development of a more detailed chronology for the fluvial and marine terraces associated with the Tejo river.

\section{Acknowledgements}

This work is part of the activities of the project POCI/CTE-GEX/ $58120 / 2004$ "Fluvial terraces, references to evaluate the fluvial incision and crustal uplift in central Portugal (western Iberia)", approved by the Fundação para a Ciência e a Tecnologia within the scope of the Programa Operacional Ciência e Inovação 2010 (POCI 2010) do Quadro Comunitário de Apoio III and co-founded by the Fundo Comunitário Europeu FEDER. Research also has been supported by the Centro de Geociências da Universidade de Coimbra, Centro de Geofísica da Universidade de Évora (Portugal), Aarhus University and Risø DTU (Denmark). The authors would like to thank Nick Debenham (Quaternary TL Surveys, U.K.) for details concerning the TL ages used here, Jorge Gouveia (Associação de Estudos do Alto Tejo) for field-work assistance, and Nuno Gracinhas for helping with the drawing in GIS. SH thanks the Joint Committee of the Nordic Natural Science Research Councils, through the Nordic Centre for Luminescence Research (a Nordic Centre of Excellence), for financial support. The stays of AAM and PPC at Risø DTU were supported by the Fundação para a Ciência e a Tecnologia (sabbatical grants). We also thank Martin Stokes and Anne Mather for their constructive reviews, which significantly improved the original manuscript.

\section{References}

Aitken, M.J., 1998. An Introduction to Optical Dating. Oxford University Press. 267 pp.

Andeweg, B., De Vicente, G., Cloetingh, S., Giner, J., Muñoz Martin, A., 1999. Local stress fields and intraplate deformation of Iberia: variations in spatial and temporal interplay of regional stress sources. Tectonophysics 305, 153-164.

Auclair, M., Lamothe, M., Huot, S., 2003. Measurement of anomalous fading for feldspar IRSL using SAR. Radiation Measurements 37, 487-492.

Blum, M.D., Törnqvist, T.E., 2000. Fluvial responses to climate and sea-level change; a review and look forward. Sedimentology 47 (Suppl. 1), 2-48.

Bonnet, S., Guillocheau, F., Brun, J.-P., Van den Driessche, J., 2000. Large-scale relief development related to Quaternary tectonic uplift of a Proterozoic-Paleozoic basement: the Armorican Massif, NW France. Journal of Geophysical Research 105, 19273-19288.

Bridgland, D.R., 2000. River terrace systems in north-west Europe: an archive of environmental change, uplift and early human occupation. Quaternary Science Reviews 19, 1293-1303.

Brocard, G.Y., Van der Beek, P.A., Bourlès, D.L., Siame, L.L., Mugnier, J.-L., 2003. Long-term fluvial incision rates and postglacial river relaxation time in the French Western Alps from ${ }^{10} \mathrm{Be}$ dating of alluvial terraces with assessment of inheritance, soil development and wind ablation effects. Earth and Planetary Science Letters 209, 197-214.

Brugal, J.-Ph., Raposo, L., 1999. Foz do Enxarrique (Ródão, Portugal): preliminary results of the analysis of a bone assemblage from a Middle Palaeolithic open site. In: Gaudzinski, Sabine, Turner, Elaine (Eds.), The Role of Early Humans in the Accumulation of European Lower and Middle Palaeolithic Bone Assemblages: Ergebnisse eines Kolloquiums (Romisch-Germanisches Zentralmuseum Forschungsinstitut fur Vor- und Fruhgeschichte Monographien, vol. 42, pp. 367-379. Mainz.

Brunnacker, K., Boenigk, W., 1983. The Rhine Valley between the Neuwied Basin and the Lower Rhenish embayment. In: Fuchs, K., von Gehlen, K., Malzer, H., Murawski, H., Semmel, A. (Eds.), Plateau Uplift, the Rhenish Shield - a Case History. SpringerVerlag, Berlin, pp. 62-72.

Burbank, D.W., Anderson, R.S., 2001. Tectonic Geomorphology. Blackwell Science. 274 pp. Bøtter-Jensen, L., Andersen, C.E., Duller, G.A.T., Murray, A.S., 2003. Developments in radiation, stimulation and observation facilities in luminescence measurements. Radiation Measurements 37, 535-541.

Cabral, J., 1995. Neotectónica de Portugal continental. Memórias do Instituto Geológico e Mineiro Portugal 31265 pp.

Cloetingh, S., Gradstein, F.M., Kooi, H., Grant, A.C., Kaminski, M., 1990. Plate reorganization: a cause of rapid late Neogene subsidence and sedimentation around the North Atlantic. Journal of the Geological Society of London 147, 495-506.

Cloetingh, S., Ziegler, P.A., Beekman, F., Andriessen, P.A.M., Matenco, L., Bada, G., GarciaCastellanos, D., Hardebol, N., Dèzes, P., Sokoutis, D., 2005. Lithospheric memory, state of stress and rheology: neotectonic controls on Europe's intraplate continental topography. Quaternary Sciences Reviews 24, 241-304.

Cunha, P.P., 1992. Estratigrafia e sedimentologia dos depósitos do Cretácico Superior e Terciário de Portugal Central, a leste de Coimbra. Ph.D. Thesis, University of Coimbra, Portugal, 262 pp.

Cunha, P.P., 1996. Unidades litostratigráficas do Terciário da Beira Baixa (Portugal). Comunicaçōes do Instituto Geológico e Mineiro 82, 87-130.

Cunha, P.P., Martins, A.A., 2000. Transição do enchimento terciário para o encaixe fluvial quaternário, na área de Vila Velha de Rodão (sector NE da Bacia do Baixo Tejo). Ciências da Terra (Univ. Nova de Lisboa) 14, 147-158.

Cunha, P.P., Barbosa, B.P., Pena dos Reis, R., 1993. Synthesis of the Piacenzian onshore record, between the Aveiro and Setúbal parallels (Western Portuguese margin). Ciências da Terra (Univ. Nova de Lisboa) 12, 35-43.

Cunha, P.P., Martins, A.A., Daveau, S., Friend, P.F., 2005. Tectonic control of the Tejo river fluvial incision during the late Cenozoic, in Ródão - central Portugal (Atlantic Iberian border). Geomorphology 64, 271-298.

Debenham, N.C., 1985. Use of U.V. emissions in TL dating of sediments. Nuclear Tracks and Radiation Measurements 10, 717-724.

Dias, R.P., Cabral, J., 1989. Neogene and Quaternary reactivation of the Ponsul river fault in Portugal. Comunicaçōes dos Serviços Geológicos de Portugal 75, 3-28.

Duller, G.A.T., 2004. Luminescence dating of Quaternary sediments: recent advances. Journal of Quaternary Science 19, 183-192.

Gutiérrez-Elorza, M., García-Ruiz, J.M., Goy, J.L., Gracia, F.J., Gutiérrez-Santolalla, F., Martí, C., Martín-Serrano, A., Pérez-González, A., Zazo, C., Aguirre, E., 2002. Quaternary. In: Gibbons, W., Moreno, T. (Eds.), The Geology of Spain. The Geological Society, pp. 335-366.

Huntley, D.J., Baril, M.R., 1997. The K content of the K-feldspars being measured in optical dating or in thermoluminescence dating. Ancient TL 15, 11-13.

Huntley, D.J., Lian, O.B., 1999. Using optical dating to determine when a sediment was last exposed to sunlight. In: Lemmen, D.S., Vance, R.E. (Eds.), Holocene Climate and Environmental Change in the Palliser Triangle: a Geoscientific Context for 
Evaluating the Impacts of Climate Change on the Southern Canadian Prairies. Geological Survey of Canada Bulletin, vol. 534, pp. 211-222.

Huntley, D.J., Hancock, R.G.V., 2001. The Rb contents of the K-feldpar grains being measured in optical dating. Ancient TL 19, 43-46.

Huntley, D.J., Lamothe, M., 2001. Ubiquity of anomalous fading in K-feldspars and the measurement and correction for it in optical dating. Canadian Journal of Earth Science 38, 1093-1106.

Huntley, D.J. Lian, O.B., 2006. Some observations on tunnelling of trapped electrons in feldspars and their implications for optical dating. Quaternary Science Reviews 25, 2503-2512.

Huot, S., Lamothe, M., 2003. Variability of infrared stimulated luminescence properties from fractured feldspar grains. Radiation Measurements 37, 499-503.

Lamothe, M., Auclair, M., Hamzaoui, C., Huot, S., 2003. Towards a prediction of long-term anomalous fading of feldspar IRSL. Radiation Measurements 37, 493-498.

Lancaster, R.R., 2005. Fluvial evolution of the Garonne River, France: integratin field data with numerical simulations. Ph.D. Thesis, Louisiana State University, 87 pp.

Maddy, D., 1997. Uplift-driven valley incision and river terrace formation in southern England. Journal of Quaternary Science 12 (6), 539-545.

Maddy, D., Bridgland, D.R., Green, C.P., 2000. Crustal uplift in southern England: evidence from the river terrace records. Geomorphology 33, 167-181.

Martins, A.A., 1999. Caracterização morfotectónica e morfossedimentar da Bacia do Baixo Tejo (Pliocénico e Quaternário). Ph.D. Thesis, University of Évora, Portugal, $500 \mathrm{pp}$.

Merritts, J., Vicent, R., Wohl, E., 1994. Long river profiles, tectonism and eustasy: a guide to interpreting fluvial terraces. Journal of Geophysical Research 99 (B7), $14031-14050$.

Murray, A.S., Olley, J.M., 2002. Precision and accuracy in the optically stimulated luminescence dating of sedimentary quartz: a status review. Geochronometria 21 , $1-16$

Murray, A.S., Wintle, A.G., 2000. Luminescence dating of quartz using an improved single-aliquot regenerative-dose protocol. Radiaton Measurements 32, 57-73.

Murray, A.S., Marten, R., Johnston, A., Martin, P., 1987. Analysis for naturally occurring radionuclides at environmental concentrations by gamma spectrometry. Journal of Radioanalytical and Nuclear Chemistry 115, 263-288.

Olley, J.M., Murray, A.S., Roberts, R.G., 1996. The effects of disequilibria in the uranium and thorium decay chains on burial dose rates in fluvial sediments. Quaternary Science Reviews (Quaternary Geochronology) 15, 751-760.

Pederson, J.L., Anders, M.D., Rittenhour, T.M., Sharp, W.D., Gosse, J.C., Karlstrom, K.E., 2006. Using fill terraces to understand incision rates and evolution of the Colorado River in eastern Grand Canyon, Arizona. Journal of Geophysical Research, 111, 1-10

Pedoja, K., Ortlieb, L., Dumont, J.F., Lamothe, M., Ghaleb, B., Auclair, M., Labrousse, B., 2006. Quaternary coastal uplift along the Talara Arc (Ecuador, Northern Peru) from new marine terrace data. Marine Geology 228, 73-91.

Pérez-González, A., 1994. Depresión del Tajo. In: Elorza, G.M. (Ed.), Geomorfologia de España, Editorial Rueda, Madrid. 526 pp.

Pillans, B.P., Chapell, J., Naish, T.C., 1998. A review of the Milankovich climatic beat: template for Plio-Pleistocene sea-level changes and sequence stratigraphy. Sedimentary Geology 211, 5-12.

Raposo, L., 1987. Os mais antigos vestígios de ocupação humana paleolítica na região de Ródão. Da Pré-História, homenagem a 0 . Veiga Ferreira. Editorial Delta, pp. 153-178.

Raposo, L., 1995a. Ambientes, territorios y subsistencia en el Paleolitico medio de Portugal. Complutum 6, 57-77.

Raposo, L., 1995b. O Paleolítico. In: Medina, J. (Ed.), História de Portugal, vol. 1. Clube Internacional do Livro, Lisboa, pp. 23-85.

Raposo, L., 2000. The Middle-Upper palaeolithic transition in Portugal. In: Stringer, C., Barton, R.N.E., Finlayson, C. (Eds.), Neanderthals on the Edge: 150th Anniversary Conference of the Forbes' Quarry Discovery, Gibraltar. Oxbow Books, Oxford, pp. 95-109.
Raposo, L., 2002. Um século de estudos no Paleolítico Médio em Portugal: balanço e perspectivas. Arqueologia 2000 - Balanço de um Século de Investigação Arqueológica em Portugal, Arqueologia e História, vol. 54, pp. 25-39. Lisboa.

Raposo, L., Silva, A.C., 1981. Elementos de cultura material na estação paleolítica de Vilas Ruivas (Ródão). Arqueologia 4, 94-104.

Raposo, L., Cardoso, J.L., 1998. O Sítio do Paleolítico Médio da Conceição (Alcochete). Centro de Estudos e Monitorização Ambiental. 74 pp.

Raposo, L., Silva, A.C., Salvador, M.. 1985. Notícia da descoberta da estacão Mustierense da Foz do Enxarrique (Ródão), I Reunião do Quaternário Ibérico (Proceedings), Lisboa, vol. 2, pp. 79-90.

Ribeiro, O., 1939. Sur la morphologie de la Basse Beira. Bulletin de l'Association de Geographes Français 122, 113-122.

Ribeiro, O., 1943a. Evolução da falha do Ponsul. Comunicações dos Serviços Geológicos de Portugal, 24, 109-123.

Ribeiro, O., 1943b. Novas observacões geológicas e morfológicas nos arredores de Vila Velha de Ródão. Publicações do Museu e Laboratório Mineralógico e Geológico da Faculdade de Ciências do Porto 32,1-24.

Ribeiro, A., Cabral, J., Baptista, R., Matias, L., 1996. Stress pattern in Portugal mainland and the adjacent Atlantic region, West Iberia. Tectonics 15, 641-659.

Shackleton, N.J., Opdyke, N.D., 1973. Oxygen isotope stratigraphy of Equatorial Pacific core V. 28-238: oxygene isotope temperatures and ice volumes on $10^{5}$ year and $10^{6}$ year scale. Quaternary Research 3, 39-55.

Sequeira, A., Cunha, P.P., Sousa, M.B., 1997. A reactivação de falhas, no intenso contexto compressivo desde meados do Tortoniano, na região de Espinhal-Coja-Caramulo (Portugal Central). Comunicaçōes do Instituto Geológico e Mineiro, Lisboa, 83, 95-126.

Silva, P.G., 2003. El Cuaternario del valle inferior del Manzanares (Cuenca de Madrid, España). Estudios Geológico 59, 107-131.

Silva, P.G., Cañaveras, J.C., Zazo, C., Sánchez-Moral, S. Lario, J., Sanz, E., 1997. 3D softsediment deformation structures: existence for Quaternary seismicity in the Madrid basin, Spain. Terra Nova 9, 208-212.

Srivastava, S.P., Roest, W.R., Kovacs, L.C., Oakey, G., Lévesque, S., Verhoef, J., Macnab, R. 1990. Motion of the Iberia since the Late Jurassic: results from detailed aeromagnetic measurements in the Newfoundland Basin. Tectonophysics 184 229-260.

Van den Berg, M.W.1996. Fluvial sequences of the Maas: a 10 Ma record of neotectonics and climate change at various time-scales. Ph.D. thesis, University of Wageningen, $181 \mathrm{pp}$.

Wallinga, J., 2002. Optically stimulated luminescence dating of fluvial deposits: a review. Boreas 31, 303-322.

Wallinga, J., Törnqvist, T., Busschers, F., Weerts, H., 2004. Allogenic forcing of the Late Quaternary Rhine-Meuse fluvial record: the interplay of sea-level change, climate change and crustal movements. Basin Research 16 (4), 535

Westaway, R., 2004. Pliocene and Quaternary surface uplift evidenced by sediments of the Loire-Allier river system (France). Quaternaire 15, 41-52.

Westaway, R., Maddy, D., Bridgland, D., 2002. Flow in the lower continental crust as a mechanism for the Quaternary uplift of south-east England: constraints from the Thames terrace record. Quaternary Science Reviews 21, 559-603.

Westaway, R., Pringle, M., Yurtmen, S., Demir, T., Bridgland, D., Rowbotham, G., Maddy, D., 2003. Pliocene and Quaternary surface uplift of western Turkey revealed by long-term river terrace sequences. Current Science 84 (8), 1090-1101.

Wintle, A.G., 1997. Luminescence dating: laboratory procedures and protocols Radiation Measurements 27, 769-817.

Wintle, A.G., Murray, A.S., 2006. A review of quartz optically stimulated luminescence characteristics and their relevance in single-aliquot regeneration dating protocols. Radiation Measurements 41, 369-391.

Wolfe, S.A. Ollerhead, J., Huntley, DJ. Campbell, C, 2002. Late Holocene dune activity in the Duchess dune field, Alberta. Geological Survey of Canada, Current Research 2002-B3, 8 pp. 